\title{
DA RESPONSABILIDADE CIVIL POR VIOLAÇÃO DE NORMAS DA CONCORRÊNCIA AO NOVO REGIME DO PRIVATE ENFORCEMENT DA CONCORRÊNCIA: DISRUPÇÃO OU CONTINUIDADE EM RELAÇÃO AO MODELO DELITUAL PORTUGUÊS?
}

\author{
FROM CIVIL LIABILITY FOR THE INFRINGEMENT OF ANTI-TRUST LAWS TO THE \\ PRIVATE ENFORCEMENT REGIME: DISRUPTION OR CONTINUITY OF THE \\ PORTUGUESE TORT LAW
}

\author{
Mafalda Miranda Barbosa'
}

RESUMO: O modelo delitual português assenta na diferença entre a ilicitude e a culpa. Para que a primeira se constate, é necessário que haja violação de um direito absoluto, violação de uma disposição legal de proteção de interesses alheios ou uma situação de abuso do direito. Ao longo do tempo, doutrina e jurisprudência foram considerando, mas não sem dúvidas e hesitações, que as normas de direito da concorrência podiam ser vistas como uma daquelas disposições legais de proteção de interesses alheios, aptas a fazer desvelar a ilicitude. $O$ novo regime do private enforcement da concorrência vem esclarecer todas as dúvidas e oferecer soluções que ultrapassam aquelas a que poderíamos chegar no quadro da responsabilidade extracontratual, ainda que daí resultem outras dificuldades no plano dogmático. Mas,

\begin{abstract}
The Portuguese tort law model is based on the distinction between unlawfulness and fault. Unlawfulness becomes when there is a violation of an absolute right, a violation of a legal norm protecting foreign interests or a situation of abuse of right. Not without doubt and hesitation, legal doctrine and case law have been considering that anti-trust laws could be understood as legal norms protecting foreign interests, and therefore able to trigger unlawfulness. The new anti-trust private enforcement regime sets new solutions and clarifies all doubts, although it brings with it new problems. But, we can still find a continuity link between the new discipline and the Portuguese tort law.
\end{abstract}

\footnotetext{
${ }^{1}$ Doutora em Direito pela Faculdade de Direito da Universidade de Coimbra. Professora da Faculdade de Direito da Universidade de Coimbra. Membro do IBERC. ORCID: 0000-0003-0578-4249. Degois: www.degois.pt/visualizador/curriculum.jsp?key=2041272967872292. E-mail: mcnmb@fd.uc.pt.
} 


Revista IBERC
v. 2, n. 2, p. 01-38, mai.-ago./2019
www.responsabilidadecivil.org

nem por isso deixamos de encontrar uma linha de continuidade entre o modelo delitual, para o qual o regime do private enforcement remete, e a nova disciplina jurídica.

Palavras-chave: Responsabilidade civil. Direito da concorrência. Private enforcement. llicitude.

Keywords: Tort law. Unlawfulness. Anti-trust law. Private enforcement.

Sumário: 1. Introdução. 2. As normas da concorrência como disposições legais de proteção de interesses alheios? 3. A lei $n^{\circ} 23 / 2018$, de 5 de Junho. 3.1. Quem é responsável? 3.2. Por que danos? 3.3. Em relação a quem? 4. Conclusões. 5. Bibliografia.

\section{INTRODUÇÃO}

Desde há algum tempo que a doutrina se questiona acerca da possibilidade de se invocarem as normas da concorrência para se fundamentar uma pretensão indemnizatória, no quadro da responsabilidade extracontratual. Nessa formulação problemática, não estaria em causa apenas um eventual direito à indemnização por parte dos concorrentes no mercado, mas também por parte de outros sujeitos, designadamente os consumidores. Para quem esteja familiarizado com o direito delitual português, alicerçado no modelo de inspiração germânica, será fácil de perceber que o nódulo central do problema se encontra no requisito da ilicitude. Em causa estaria, afinal, e diante da mera lesão de interesses económicos do sujeito, a possibilidade de se mobilizarem as normas da concorrência como disposições legais de proteção de interesses alheios, aptas a garantir a desvelação da ilicitude delitual, na sua segunda modalidade.

O aproveitamento das normas da concorrência no quadro de relações entre privados acaba por receber, porém, um tratamento mais amplo, conhecido por private enforcement. Nas palavras de Miguel Ferro, o fenómeno

\footnotetext{
"abrange todas as circunstâncias em que uma pessoa promove uma ação na qual invoca normas europeias e/ou nacionais de concorrência em prol dos seus direitos ou interesses, ou de direitos ou interesses coletivos ou difusos, sem que esteja diretamente em causa a aplicação de contraordenações ou
} 


\section{Revista IBERC}

v. 2, n. 2, p. 01-38, mai.-ago./2019

www.responsabilidadecivil.org

de medidas ao abrigo da lei da concorrência ou do direito europeu da concorrência"².

A intencionalidade com que pode ser captado o fenómeno leva-nos mais longe. $\mathrm{Na}$ verdade, o private enforcement é entendido do ponto de vista da necessidade de reforço da eficácia das normas da concorrência. Nessa medida, tem vindo a ser estabelecida uma disciplina específica que Ihe seja aplicável e que vai além da simples mobilização das normas de concorrência no quadro de relações entre privados e, portanto, fora do domínio contraordenacional. O private enforcement passa, então, a ser visto como um mecanismo que garante não só a compensação dos lesados, como também um aumento da eficácia das normas ${ }^{3}$.

Em Portugal, foi recentemente aprovado o regime jurídico do private enforcement da concorrência que, embora remeta expressamente para o artigo $483^{\circ} \mathrm{CC}$, e, portanto, para o regime da responsabilidade extracontratual, introduz regras especiais que suscitam a dúvida de saber se ele introduz uma disrupção no modelo delitual ou se entre o regime geral e o regime especial se denotam linhas de continuidade que permitem que o segundo seja interpretado à luz da intencionalidade e dos princípios que enervam o primeiro. Ao tentarmos responder a essa questão, revisitamos o modelo delitual português, nos seus principais contornos ${ }^{4}$.

\footnotetext{
${ }^{2}$ Miguel Sousa FERRO, "Jurisprudência de private enforcement”, Jurisprudência portuguesa de Direito da Concorrência, 2016 (ebook disponível em http://www.cideeff.pt/xms/files/Projeto_4_grupo_III/Jurisprudencia_de_Private_Enforcement.pdf).

${ }^{3}$ Considerando que o private enforcement pode garantir um aumento da prevenção e da compensação dos lesados e sublinhando que ele não exclui o public enforcement, que deve ser visto como complementar: VAN DEN BERGH, Roger. Competition law and the persistng collective action problema. Maastricht Journal of European and Comparative Law, 20, 2013, p. 01 ss. A este propósito ainda, BURBANK, Steven B.; FARHANG, Sean; KRITZER, Herbert M. Private enforcement. Lewis \& Clark Law Review, 17, 2013, p. 637 ss, em especial: BURBANK, Steven B.; FARHANG, Sean; KRITZER, Herbert M. Private... p. 662 ss, referindo-se às vantagens potenciais do fenômeno, e BURBANK, Steven B.; FARHANG, Sean; KRITZER, Herbert M. Private... p. 667, considerando as suas desvantagens. Na relação com a proteção do consumidor, BURBANK, Steven B.; FARHANG, Sean; KRITZER, Herbert M. Private... p. 703 e WOODS, Donncadh; SINCLAIR, Alisa; ASHTON, David. Private enforcement of community competition law: modernisation and the road ahead. Competition Policy Newsletter, 2, 2004, p. 31 ss, considerando entre outras vantagens que aumenta a prevenção e reforça o cumprimento da lei, ao mesmo tempo que garante a compensação das vítimas e permite que se lide com certo tipo de casos de forma adequada.

4 Para outros desenvolvimentos, BARBOSA, Mafalda Miranda. Private enforcement do direito da concorrência em Portugal: o antes, o agora e o depois da responsabilidade civil por violação de normas concorrenciais. O Direito, 149, 2017/II, 277-310; CAPELO, Maria José; BARBOSA, Mafalda Miranda; HENRIQUES, Miguel Gorjão. Private Enforcement do direito da concorrência. Comentário à Lei n²3/2018, de 5 de Junho (no prelo). Reproduzem-se aqui muitas das conclusões a que chegámos na investigação conducente à elaboração dos estudos citados.
}

Revista IBERC, Minas Gerais, v. 2, n. 2, p. 01-38, mai.-ago./2019 


\section{Revista IBERC}

v. 2, n. 2, p. 01-38, mai.-ago./2019

www.responsabilidadecivil.org

\section{AS NORMAS DA CONCORRÊNCIA COMO DISPOSIÇÕES LEGAIS DE PROTEÇÃO DE INTERESSES ALHEIOS?}

O preceito central em matéria de responsabilidade civil extracontratual, no ordenamento jurídico português, é o artigo $483^{\circ} \mathrm{CC}$. Aí, acolhe-se, claramente, o modelo proposto por Ihering e consagrado no BGB, assente na dualidade entre culpa e ilicitude. Se a primeira é imprescindível, exceto nos casos de responsabilidade objetiva, a segunda também tem de estar necessariamente preenchida, traduzindo-se na violação de direitos absolutos, na violação de disposições legais de proteção de interesses alheios e no abuso do direito. Não é, portanto, difícil de perceber a sintonia com o ordenamento jurídico alemão, razão pela qual se torna imprescindível olhar - ainda que simplificadamente - para essa que foi a nossa fonte de inspiração.

$\mathrm{Na}$ verdade, o direito delitual alemão baseia-se no chamado Enumerationprinzip, nos termos do qual apenas determinados bens indicados pela lei (§823 I BGB) são objeto de tutela. A par desta previsão, o §823 II BGB estabelece que a indemnização pode resultar da violação de disposições legais de proteção de interesses alheios, e o §826 considera que a violação dolosa dos bons costumes pode constituir fonte de responsabilidade civil. Quer isto dizer que, embora a culpa seja exigida - em regra - como requisito para o ressarcimento, sendo ainda hoje excecionais as hipóteses de responsabilidade objetiva, ela não é bastante para alicerçar uma pretensão indemnizatória procedente. Exige-se o preenchimento de um filtro objetivo de seleção dessas mesmas pretensões - a ilicitude. Confrontamo-nos, portanto, com três pequenas cláusulas que permitem desvela-la. De acordo com os estudiosos ${ }^{5}$, a consagração destas três pequenas cláusulas de ilicitude afigura-se essencial para garantir a separação entre os dois níveis de sindicância propostos por lhering: por um lado a ilicitude, por outro lado a culpa.

Também em Portugal, uma pretensão indemnizatória só pode ser procedente se estiver preenchida a ilicitude, que é desvelada por uma de três vias: violação de direitos absolutos, violação de disposições legais de proteção de interesses alheios e o abuso do direito. $\mathrm{Na}$ falta de violação de um direito absoluto e perante o caráter excecional deste abuso do direito, entende-se por que razão pode ser tão importante a mobilização de uma disposição legal de proteção de interesses alheios no quadro da tentativa de ressarcimento dos prejuízos causados por uma conduta violadora das normas da concorrência. É que aí, via de regra, o que

\footnotetext{
${ }^{5}$ CORDEIRO, Menezes. Da responsabilidade civil dos administradores das sociedades comerciais, Lex, 1997, p. 437, num sentido análogo ao que vai intencionado no nosso texto.
}

Revista IBERC, Minas Gerais, v. 2, n. 2, p. 01-38, mai.-ago./2019 


\section{Revista IBERC}

v. 2, n. 2, p. 01-38, mai.-ago./2019

www.responsabilidadecivil.org

está em causa é a pura preterição de interesses económicos, pelo que será esta a única via de a alicerçar.

Torna-se, por isso, mister compreender o que são e como podem funcionar a este nível as disposições legais de proteção de interesses alheios.

A aparente simplicidade enunciativa da segunda modalidade de ilicitude extracontratual - "violação de disposições legais de protecção de interesses alheios" - é proporcionalmente inversa ao grau de complexidade que a sua mobilização em concreto acarreta $^{6}$. E se a dúvida que se podia concitar em alguns espíritos acerca da bondade de autonomização dela por referência à violação de direitos absolutos se esvanece pelo rememorar da lição de Ihering e do seu acolhimento por Guilherme Moreira, dado que, ao privilegiar a separação estanque entre culpa e ilicitude, tinha de ser garantida a sindicância autonomizada da segunda, tornando-se imperioso, fora do quadro dos direitos absolutos, encontrar uma norma que viesse tutelar determinados interesses, nem por isso os problemas prático-normativos que daí resultam são eliminados ${ }^{7}$.

Desde logo é o alcance de disposição legal a ser posto em causa. Pois que, se no tempo da sua emergência, os ares do positivismo poderiam tornar líquida a resposta - no sentido da sua identificação com uma norma legal tout court -, hodiernamente, a recusa fundada de identificação do direito com a mera legalidade formal, o reconhecimento da índole constitutiva da tarefa judicativa e a obliteração do carácter injuntivo do cânone metodológico consagrado nos artigos iniciais do Código Civil legitimam a pergunta: interpretar-se-á ou não o segmento do artigo $483^{\circ} \mathrm{CC}$ no sentido de nele integrar as normas de raiz jurisprudencial ${ }^{8}$ ?

\footnotetext{
${ }^{6}$ A propósito da importância prático-normativa da consagração desta segunda modalidade de ilicitude, dicotomizando o domínio pessoal do domínio patrimonial (SERRA, Vaz. Requisitos da responsabilidade civil. Boletim do Ministério da Justiça, $\mathrm{n}^{\circ}$ 92, p. 94-95; MONTEIRO, Sinde. Responsabilidade por conselhos, informações e recomendações, Almedina, Coimbra, 1989. p. 237 ss). Mais recentemente, com amplo desenvolvimento, LEITÃO, Adelaide Menezes. Normas de protecção e danos puramente patrimoniais. Almedina, Coimbra, 2009. Na doutrina portuguesa, acerca desta modalidade de ilicitude delitual, vide, igualmente, VARELA, Antunes. Das obrigações em geral, vol. I. Coimbra: Almedina, 2003. p. 540 ss; COSTA, Almeida. Direito das Obrigações. $12^{2}$ ed. Coimbra: Almedina, 2009. p. 488 ss.

${ }^{7}$ A diferença entre o parágrafo I e II do § 823 BGB ou entre a primeira e a segunda modalidade de ilícito em Portugal esbateu-se no momento em que os bens da personalidade passaram a ser entendidos como direitos subjetivos. Neste sentido, cf., entre nós, MONTEIRO, Sinde. Responsabilidade... p. 237 e SERRA, Vaz. Requisitos... p. 94 ss.; BARBOSA, Mafalda Miranda. Do nexo de causalidade ao nexo de imputação: contributo para a compreensão da natureza binária e personalística do requisito causal ao nível da responsabilidade civil extracontratual. Dissertação de doutoramento. Cascais: Princípia, 2013. p. 586.

${ }^{8}$ No sentido de considerar que em causa estão apenas as leis enquanto fonte de direito definida no artigo $1^{\circ}, n^{\circ} 2$ do CC (MONTEIRO, Sinde. Responsabilidade... p. 246. Admite, porém, que o conceito seja entendido em termos materiais. Assim, em causa estaria não só a lei em sentido próprio (emanada da Assembleia da República), mas todos os restantes atos legislativos e regulamentares. Essencial é que ela provenha de um órgão estadual. Sinde Monteiro, colhendo a lição germânica, apresenta os outros elementos essenciais da qualificação de uma norma como disposição legal de proteção de interesses alheios: 1) tem de proibir um determinado comportamento, acantonando-se aí a nota de ilicitude que se
}

Revista IBERC, Minas Gerais, v. 2, n. 2, p. 01-38, mai.-ago./2019 


Revista IBERC
v. 2, n. 2, p. 01-38, mai.-ago./2019
www.responsabilidadecivil.org

Erigida em modalidade charneira da responsabilidade, a violação de direitos absolutos assume-se como pórtico de entrada do instituto, identificando-o, as mais das vezes, por antonomásia.

Seria, por isso, estranho que se invertesse a arquitetura consagrada, pela abertura desmedida da cláusula delitual, a permitir uma ampla tutela do património ${ }^{9}$, pelo que se impõe a adoção de critérios de circunscrição da relevância da violação das disposições legais de proteção de interesses alheios. Em causa terá de estar a violação de uma norma legal, isto é, proveniente de um órgão estadual, posto que a legitimidade para edificar a referida proteção de certos interesses, ainda que não tutelados por via da atribuição ou reconhecimento de um direito subjetivo, reside no poder legislativo. Por outro lado, essa norma legal tem de proteger determinados interesses alheios, não bastando que vise a tutela de meros interesses gerais ou coletivos.

pretende desvelar, razão pela qual não podem ser consideradas para o efeito as normas que estabelecem nulidades de determinados atos (MONTEIRO, Sinde. Responsabilidade... p. 247 e 225); 2) tem de visar proteger interesses alheios, isto é, tem se dirigir à tutela de uma pessoa ou círculo de pessoas, não sendo suficiente que tenha por objetivo a protecção da coletividade em geral (MONTEIRO, Sinde. Responsabilidade... p. 249); 3) importa que a norma vise a proteção daquela pessoa contra aquela espécie de danos e contra aquele modo de lesão (aquele tipo de perigos) (MONTEIRO, Sinde. Responsabilidade... p. 249-234).

Não respondendo diretamente à questão, mas indiciando uma solução positiva, pela recusa de autonomização do abuso do direito como modalidade de ilicitude delitual (SOUSA, Capelo de. Teoria Geral do Direito Civil. Coimbra: Coimbra Editora, 2003. p. 205, n. 504. O autor considera ser o artigo $334^{\circ}$ CC uma norma de protecção de interesses alheios. Ora, o carácter aberto do preceito, a impor a sua redensificação em sede judicial, implica que seja o julgador a, em face das exigências do caso concreto, descobrir o dever de conduta concretamente violado. Em causa, portanto, a dilemática questão de saber se os deveres de prevenção do perigo se reconduzem à primeira modalidade de ilicitude, à segunda modalidade ou se se podem autonomizar das previsões do $\S 823$ BGB (correspondente ao nosso artigo $\left.483^{\circ} \mathrm{CC}\right)$.

$\mathrm{Na}$ doutrina estrangeira, entre outros, para a especificação do conceito de disposição legal de protecção de interesses alheios, cf. RüMELIN. Die Verwendung der Causalbegriffe im Straf und Civilrecht, Archiv für die civilistiche Praxis, 90, Heft 2, 1900, p. 186 ss; KNÖPFLE, Robert. Zur Problematik der Beurteilung einer Norm als Schutzgesetz um Sinne des § 823 Abs. 2 BGB, Neue Juristische Wochenschrift, 1967, p. 697702; CANARIS, Claus-Wilhelm. Schutzgesetze-Verkehrspflichten-Schutzpflichten. Festschrift für Karl Larenz zum 80. Geburtstag am 23. April 1983, München, Beck, 1983, p. 49 s; DöRNER, Heinrich. Zur Dogmatik der Schutzgesetzverletzung, Juristische Schulung. Zeitschrift für Studium und Ausbildung, 27. Jahrgang, 1987 , p. 522 s.

${ }^{9}$ No mesmo sentido, inter alia, MONTEIRO, Sinde. Responsabilidade... p. 253; CANARIS, Claus-Wilhelm. Schutzgesetze-Verkehrspflichten-Schutzpflichten, $49 \mathrm{~s}$. Canaris mostra-se, por isso, muito restritivo na qualificação das normas que podem aceder à qualificação de disposições de proteção. Sobre o ponto, em sentido tendencialmente concordante, veja-se, entre nós, MONTEIRO, Sinde. Responsabilidade... p. 253. Em sentido contrário, apresentando razões para a não circunscrição das normas de proteção às normas penais, veja-se Adelaide LEITÃO, Menezes. Normas de protecção... p. 429. Igualmente, LEITÃO, Menezes. Normas de protecção... p. 418 (questionando se, para além da questão da eficácia horizontal dos direitos fundamentais, as normas constitucionais podem ser utilizadas como disposições de proteção) e LEITÃO, Menezes. Normas de protecção... p. 377 (onde se coloca o problema de saber se as normas internacionais e as normas comunitárias podem valer como tal). Veja-se, ainda, BARBOSA, Mafalda Miranda, Lições de Responsabilidade... p. 2017.

Revista IBERC, Minas Gerais, v. 2, n. 2, p. 01-38, mai.-ago./2019 


\section{Revista IBERC}

v. 2, n. 2, p. 01-38, mai.-ago./2019

www.responsabilidadecivil.org

Não quer isto dizer que a proteção desses interesses genéricos não possa integrar-se na teleologia da norma. Significa sim que esta deve integrar especificamente a tutela dos interesses alheios (de uma pessoa ou grupo particular de pessoas) entre os seus fins. Mais do que isso, a norma deve proteger - proibindo ou impondo um comportamento - contra um especial risco (contra um determinado dano infligido de um certo modo). Afirma Brüggemeier que importa saber se a norma tem ou não em vista a proteção de outros. O § $823 \mathrm{II}$, tal como o $823 \mathrm{I}$, assume-se como um âmbito de proteção de um especial interesse individual.

Neste contexto, a tradicional fórmula, segundo a qual se impõe que a norma proteja não só a coletividade, mas também erija a proteção de uma pessoa ou grupo de pessoas, é uma tautologia. O problema passa por saber como determinar a finalidade da norma, abrindose dois caminhos: a) saber se a norma também prossegue a proteção de um interesse individual; b) saber se a proteção jurídica delitual desses interesses privados se justifica. Nesta medida, a norma deve proteger especiais interesses privados (sachlichen Schutzbereichs), de um especial círculo de pessoas (personellen Schutzbereichs), contra um especial risco (o bem jurídico deve ter sido violado pelo modo contra o qual a norma edificava a sua proteção modaler Schutzbereich $)^{10}$. A desvelação da segunda modalidade de ilicitude depende da assimilação do âmbito de relevância concreto do caso pelo âmbito de relevância hipotético, teleologicamente compreendido, de uma norma primária ordenadora de condutas, pelo que a imputação assim vazada transpira essa dependência e apresenta um recorte específico.

$\mathrm{Na}$ verdade, a insuficiência do resultado para justificar a reação do ordenamento faz impender sobre a conduta o peso acrescido de ancoragem da imputação que se estabelece. $\mathrm{E}$, exatamente por isso, ela apresenta uma concretude - própria da proibição normativa que foi posta em causa - que não pode deixar incólumes as soluções ensaiadas aquando da mobilização do sistema à luz das especificidades do caso concreto. Com a desvelação da ilicitude por via da violação de uma disposição legal de proteção de interesses alheios, antecipa-se a tutela delitual, segundo a lição da doutrina.

Sublinha Sinde Monteiro que "a culpa tem agora de se referir apenas à própria violação da norma e já não à violação dos bens jurídicos" ${ }^{\prime 1}$. $\mathrm{O}$ alcance exato da afirmação só pode, contudo, ser logradamente apreendido se e quando tivermos em conta a estrutura da norma violada, reforçando-se a nota de dependência a que já fizemos alusão. Haveria como

${ }^{10}$ BÜGGERMEIER, Gert. Haftungsrecht. Struktur, Prinzipen, Schutzbereich zur Europäisierung des Privatrechts, Springer. Berlin Heidelberg: New York, 2006, p. 537 ss.

${ }^{11}$ MONTEIRO, Sinde. Responsabilidade... p. 239. No mesmo sentido, cf., inter alia, TRAEGER. Der Kausalbegriff im Straf und Zivilrecht. Malburg: Elwert Verlag, 1904, 377-379; LARENZ/CANARIS. Lehrbuch des Schuldrechts. Band 2, Halbband 2, 13 Auflage, München: Verlag C. H. Beck, 1994, p. 445. Cf., nota de rodapé seguinte.

Revista IBERC, Minas Gerais, v. 2, n. 2, p. 01-38, mai.-ago./2019 


Revista IBERC
v. 2, n. 2, p. 01-38, mai.-ago./2019
www.responsabilidadecivil.org

que uma antecipação da tutela. Tal antecipação equivaleria a uma antecipação do juízo de culpa, que apenas tem de se referir à violação da norma ${ }^{12}$. Por outro lado, a violação da norma

12 MONTEIRO, Sinde. Responsabilidade... p. 239. No mesmo sentido, TRAEGER. Der Kausalbegriff..., p.
377-379; LARENZ/CANARIS. Lehrbuch..., p. 445; VON BAR, Christian. Delilktsrecht - Empflieht es sich,
die Voraussetzungen der Haftung für unerlaubte Handlungen mit Rücksicht auf die gewandelte
Rechtswirklichkeit und die Entwicklungen in Rechtsprechung und Lehre neu zu ordnen? Wäre es
insbesondere zweckmässig, die Grundtatbestände der $\S 823$ Abstätze 1 und 2 , 826 BGB zu erweitern
oder zu ergänzen?“, Gutachten und Vorschläge zur überarbeitung des Schuldrechts herausgegeben vom
Bundesminister der Justiz, Bd. II, Köln: Bundesanzeiger Verlag, 1981, p. 1696, sustentando que, no caso
de violação de uma norma de perigo abstrato, a culpa se limita à ofensa da norma e que há inversão do
ónus da prova quanto a ela. Em sentido diverso, STOLL, Hans. Kausalzusammenhang und Normzwek im Deliktsrecht. Tübingen: Mohr, 1968, p. 22 ss. O Autor considera que o $\$ 823$ II BGB não se esgota na violação da norma, sustentando que a culpa também se deve referir ao interesse violado, uma vez que, se assim não fosse, o risco de responsabilidade tornar-se-ia tanto maior quanto mais geral e abstrata fosse a norma que preconiza uma proibição de pôr em perigo. Rejeitando o princípio geral de que, quanto mais abstrata seja a norma, mais severa deve ser a responsabilidade, cf. Sinde MoNTEIRo (Seguro automóvel...), para o que acaba por não prescindir totalmente do juízo de adequação a este nível.

De notar, igualmente, que, de acordo com o modelo imputacional que tivemos oportunidade de delinear na nossa dissertação de doutoramento, no caso da primeira modalidade de ilicitude, desenha-se, em concreto, a partir da preterição de deveres de segurança no tráfego, onde se incluem deveres de cuidado (que, uma vez lesados, permitem desvelar a culpa), uma esfera de risco/responsabilidade que estará na base da imputação de um resultado ao agente. Ora, a culpa há-de referir-se a essa esfera de responsabilidade e não a todos os danos-eventos que surjam. Sobre o ponto, BARBOSA, Mafalda Miranda. Do nexo de causalidade... p. 914 ss.

Veja-se, ainda, LINDENMAIER. Adäquate Ursache und nächste Ursache. Zur Kausalität im allgemeinen bürgerlichen Recht und in den Allgemeinen Deutschen Seeverischerungsbedingungen. Festschrift für Wüstendörfer, Zeitschrift für das Gesamte Handelsrecht und Konkursrecht, 113 Band, 3/4, 1950. p. 206 e 215. Considera que a culpa/previsibilidade tem de existir em relação ao efeito danoso imediato, mas não em relação aos danos subsequentes; VON CAEMMERER. Die Bedeutung des Schutzbereichs einer Rechtsnorm für die Geltendmachung von Schadensersatzansprüchen aus Verkehrsunfällen. Deutsches Autorecht 70, p. 283 s. e 290, sustenta que a culpa não tem de estar referida à direta lesão do bem jurídico, mas à criação de uma fonte de perigo; Rıstow, Till. Die psychische Kausalität im Deliktsrecht. Europäische Hochschulschriften, Frankfurt am Main: Peter Lang, 2003, p. 217, sublinha que, ao nível da responsabilidade por culpa, esta não tem de se referir à direta violação do bem jurídico, mas à criação da fonte de perigo.

Entre nós, a este propósito, SERRA, Vaz. Obrigação de indemnização. Colocação. Fontes. Conceito e espécies de dano. Nexo causal. Extensão do dever de indemnizar. Espécies de indemnização. Direito de abstenção e de remoção. Boletim do Ministério da Justiça, n. 84, Março 1959, p. 31, defendendo que o agente deve ter previsto o primeiro resultado contrário ao direito; MONTEIRO, Sinde. Responsabilidade... p. 318 (considerando que a culpa se deve referir à ofensa dos direitos e não apenas à infração do dever, como acontece na segunda modalidade de ilicitude, mas admitindo que tal não implica uma diferença de monta, já que é difícil conceber uma violação culposa de um dever no tráfego que conduza a uma lesão não culposa de direitos absolutos, exceto se eles fossem estabelecidos de forma abstrata).

Com isto acabamos por ser confrontados com outras nervuras problemáticas. Elas alimentam-se, sobretudo, por uma preocupação de coerência intrassistemática. A segunda modalidade de ilicitude: a) serve para ampliar o leque de bens jurídicos/interesses tutelados por via delitual; b) antecipa a tutela dos bens jurídicos protegidos ao nível da primeira modalidade de ilicitude. Um dos índices dessa antecipação passa pela referência da culpa, não ao resultado lesivo, mas à violação normativa. Não implicará a interpretação expendida a introdução de um fator de perturbação na medida em que se torna mais difícil a perceção da mais-valia das normas de proteção de interesses alheios? Não cremos que assim seja. Desde logo, há que perguntar "por que razão é que a antecipação da tutela ocorre por referência a interesses menos valiosos e não existe sempre que esteja em causa a violação de direitos absolutos"? Se a justificação pode passar pela intencionalidade que presidiu à edificação de um modelo delitual assente na estrutura iheringuiana, bem como pela perceção da existência de comunidades de risco estabilizadas

Revista IBERC, Minas Gerais, v. 2, n. 2, p. 01-38, mai.-ago./2019 


\section{Revista IBERC}

v. 2, n. 2, p. 01-38, mai.-ago./2019

www.responsabilidadecivil.org

implica, segundo a posição de alguns autores, uma presunção de culpa ${ }^{13}$. In fine, tal antecipação teria consequências ao nível da causalidade ${ }^{14}$. Prescindir-se-ia a este nível da ideia de adequação e da ideia de probabilidade que lhe anda associado, porque o que revelaria seria saber se o dano se inscreve ou não entre aqueles que a norma visava obliterar.

Estas ideias não devem, contudo, ser sobrevalorizadas.

Para o perceber, tenhamos em conta algumas ideias: em primeiro lugar, há que ter presente o ponto de referência da culpa no quadro da primeira modalidade de ilicitude ${ }^{15}$; em segundo lugar, não se podem ignorar os mais recentes desenvolvimentos doutrinários a propósito da causalidade. Ao afastarem-nos da ideia de probabilidade e ao apontarem-nos para uma perspetiva imputacional assente na edificação de uma esfera de risco/responsabilidade que dialoga com outras esferas de risco/responsabilidade, acabamos por encontrar uma resposta diversa para o problema do ónus probatório, com a qual nos aproximamos, apesar de centrados noutros fundamentos, da flexibilização que era conseguida exclusivamente por via da segunda modalidade de ilicitude ${ }^{16}$.

que determinam a intervenção do legislador, pronta a ser aproveitada em sede aquiliana, então perceberemos que, inexistindo uma disposição legal de proteção de interesses alheios, deixa de se presumir a esfera de risco/responsabilidade, que há-de ser construída em concreto, com apelo às circunstâncias paradigmáticas e exemplares, e provada pelo lesado. No fundo, ao contrário do que acontece se estivermos no seio da segunda modalidade de ilicitude, a contemplação da lesão concretamente experimentada vai ser essencial. Com isto podemos dizer que a culpa se refere ao resultado. Trata-se, contudo, do resultado imediatamente verificado e não daqueles danos subsequentes que, se forem também danos-lesão, colocarão problemas ao nível da própria imputação.

${ }^{13}$ A este ensejo podemos referir duas grandes posições na doutrina: os Autores que defendem a existência de uma verdadeira inversão do ónus probandie os que se limitam a falar de uma presunção simples. MONTEIRO, Sinde. Responsabilidade... p. 265. Dando conta da divergência, vide, também, LEITÃO, Adelaide Menezes. Normas de protecção... p. 728.

Cf., a este propósito: STOLL, Hans. Haftungsverlagerung durch beweisrechtliche Mittel. Archiv für die civilistische Praxis, 176, 1976. p.145-196, em especial na p. 179. O autor diz que não é possível falar, em geral, de uma presunção de culpa e de causalidade ao nível da violação de normas de proteção tendo em conta a estrutura e o conteúdo multiformes de tais prescrições legislativas. Em regra, poder-se-á falar de uma alteração do ónus probandi ao nível das normas de pôr em perigo abstrato.

${ }^{14}$ Adelaide Menezes LEITÃo. Normas de proteção, p. 689. Diz-nos a autora que "(...) [a] característica da ilicitude assente na própria ação e não num resultado determinado, designadamente a lesão de um bem jurídico determinado, implica consequências ao nível do nexo de causalidade. Com efeito, a causalidade tem de ser equacionada no contexto de normas de pôr em perigo".

LARENZ/CANARIS, Lehrbuch..., p. 433. Salientam os autores, no quadro da segunda modalidade de ilicitude, que importa que a pessoa lesada figure entre as que são protegidas pela pretensão indemnizatória. E além disso importa que o interesse seja tutelado pela norma. Há que saber, em concreto, se o risco específico nesta previsto se verificou. Mas, contrariamente ao entendimento do $\mathrm{BGH}$, não se trata de uma questão de causalidade. Na verdade, segundo os insignes juristas, não questionamos aí se a violação da norma foi causal, já que o que tem de ser causal é a conduta do lesante em relação ao dano. A violação da norma diz respeito à Tatbestandsmässigkeit e à Rechtswidrigkeit, só sendo relevante a esse ensejo; já a causalidade representa uma conexão entre a conduta e o dano.

Veja-se, ainda, SCHICKEDANZ, Erich. Schutzwecklehre und Adäquanztheorie. Neue Juristische Wochenschrift, 24. Jahrgand, 1. Halbband, 1971. p. 917 ss.

${ }^{15} \mathrm{Cf}$. o que se disse na nota de rodapé 10.

${ }^{16}$ Sobre o ponto, BARBOSA, Mafalda Miranda. Do nexo de causalidade... passim.

Revista IBERC, Minas Gerais, v. 2, n. 2, p. 01-38, mai.-ago./2019 


\section{Revista IBERC}

v. 2, n. 2, p. 01-38, mai.-ago./2019

www.responsabilidadecivil.org

A grande mais-valia da segunda modalidade de ilicitude parece, portanto, encontrarse no alargamento dos bens jurídicos que podem ser tutelados ao nível extracontratual. Mas, a este propósito, os autores questionam se a segunda modalidade de ilicitude se limita a antecipar e reforçar a tutela que é dispensada aos bens jurídicos tutelados ao abrigo da primeira modalidade de ilicitude ou se se verifica, de facto, um alargamento dos interesses merecedores de proteção. A questão foi colocada sobretudo na Alemanha, a propósito da relação entre o § 823 I e o § 823 II BGB, mas deve ser ponderada entre nós, atenta a similitude dos modelos aquilianos com que estamos a operar.

Ora, a nossa resposta não pode ser senão a de que - para além de antecipar e reforçar a tutela, compreendida nos moldes atrás enunciados - há um efetivo alargamento do leque de bens jurídicos protegidos pelo ordenamento jurídico. Contra o que sustentam alguns autores $^{17}$, não tem de haver uma coincidência entre os interesses aqui intencionados e os bens jurídicos protegidos, ex via direito absoluto, ao abrigo da primeira modalidade de ilicitude. $\mathrm{O}$ segmento em apreço do artigo $483^{\circ}, \mathrm{n}^{\circ} 1 \mathrm{CC}$ - embora da forma prudente que impele à contemplação da conduta e não apenas do resultado - é de molde a alargar o espetro dos valores tutelados delitualmente. De outro modo, tornar-se-ia incompreensível - se bem que não despicienda - a bifurcação criteriológica ${ }^{18}$. O que não significa, porém, que não possa haver uma coincidência entre eles ${ }^{19}$. Pensemos na norma que proíbe a circulação automóvel a uma

\footnotetext{
${ }^{17}$ Assim, cf. TRAEGER. Der Kausalbegriff. p. 376 ss., considerado que o § 823 II não acrescenta nada ao § 823 । BGB, sendo o seu alcance meramente subjetivo, ou seja, ele só teria relevo em sede de determinação da culpa que se passa a referir à norma violada e não ao resultado. Para ele, não é bastante a violação culposa da norma de proteção, sendo necessário que o resultado lesivo implique a preterição de um dos bens jurídicos previstos no § 823 I BGB.

${ }^{18}$ Assim, na Alemanha, o $\$ 823$ I serviria para tutelar direitos e bens jurídicos com eficácia erga omnes, enquanto o § 823 II se destinaria à proteção de interesses.

Sobre o ponto, cf., igualmente, CANARIS, Claus-Wilhelm. Schutzgesetze-VerkehrspflichtenSchutzpflichten... p. 49-ss, considerando que o § 823 II BGB cumpre uma dupla função: complemento e concretização da primeira modalidade de ilicitude; alargamento da tutela nos delitos de perigo abstrato. Caso a disposição legal de proteção de interesses alheios vise tutelar um dos bens elencados no $\S 823$ । BGB, ela funciona como uma mera concretização da tutela; na hipótese inversa, o preceito aproxima-se do $\$ 826$ BGB.

Veja-se, ainda, KOHTE, Wolfhard. Normzweck und Interessenabwägung bei der Auslegung des § 823 II BGB, - BGH NJW 1987, 1818. Jura, 1988, Heft 3, p. 125 ss., em especial p. 128 s., sublinhando a importância da segunda modalidade de ilicitude ao apresentar a sua dupla função: alargamento das hipóteses susceptíveis de ressarcimento; repercussão em sede processual.

${ }_{19}$ Importa, a este ensejo, referir que dialogam na doutrina duas posições acerca da concreta comunicação entre as duas modalidades de ilicitude. De um lado, encontramos os autores que, constatando a coincidência de bens jurídicos tutelados por uma e outra, sustentam que a segunda via de desvelação do ilícito não pode funcionar no sentido da limitação do âmbito de proteção conferido pela primeira. Nesse sentido, cf. MONTEIRO, Sinde. Responsabilidade..., p. 254 s.; PINTO DE OLIVEIRA, Nuno, O problema da ilicitude das condutas conformes às leis de protecção do ambiente. Acórdão do Supremo Tribunal de Justiça de 17.1.2002. Cadernos de Direito Privado, n. 12, Outubro/Dezembro, 2005, p. 13-20; LEITÃO, Adelaide Menezes. Normas de protecção... p. 561. De outro lado, estariam aqueles que sustentam que a norma de proteção positivaria uma ponderação entre interesses do lesante e do lesado pelo que qualquer conduta que, atentando bens jurídicos nela tutelados, não preenchesse o seu
}

Revista IBERC, Minas Gerais, v. 2, n. 2, p. 01-38, mai.-ago./2019 


\section{Revista IBERC}

v. 2, n. 2, p. 01-38, mai.-ago./2019

www.responsabilidadecivil.org

velocidade superior a $120 \mathrm{~km} / \mathrm{h}$ para evitar o perigo dos outros utentes da via. Estaríamos, aí, diante de uma concretização de determinados deveres de cuidado ${ }^{20}$.

A partir dela, tomada como exemplo, e imaginado que $B$, conduzindo a $180 \mathrm{~km} / \mathrm{h}$, colide com o veículo de $C$, ferindo-o gravemente, construamos duas hipóteses discursivas diversas, cada uma das quais centrada numa específica modalidade de ilicitude extracontratual $^{21}$. No que à primeira tange, ela desvelar-se-ia pelo resultado lesivo, ou seja, pela violação do direito à integridade física. Essencial seria, contudo, e deixando por ora de lado o nexo de causalidade exigível (entendido, como deve ser, como nexo de imputação), que o lesado viesse provar a culpa do agente perpetrador do ilícito. Para tanto, entende-se ser a culpa um desvio na conduta que era exigível a um homem médio, traduzindo-se - na sua conformação básica da negligência - na preterição de um dever de cuidado, a pressupor a previsibilidade do dano e a exigibilidade de adoção de um comportamento diverso. E sustentase que a mesma deve ser referida à violação do direito de que se parte e não aos danos concretos em que a mesma se refrate (ou, de acordo com o modelo imputacional por nos desenhado a que já fizemos referência, à esfera de responsabilidade que se erige a partir de tal preterição) ${ }^{22}$.

Já no âmbito de relevância da segunda modalidade de ilicitude, algumas notas de dissenso haveriam de ser sublinhadas, pese embora as mesmas sejam amparadas por zonas de convergência. A ilicitude seria matizada, não pela violação da integridade física, mas pela quebra de uma norma legal de proteção de interesses alheios. Na sindicância dela, urgia, em primeiro lugar, num juízo interpretativo que se afigura essencial, indagar acerca da referida natureza da prescrição normativa mobilizada. Para tanto, há que ter em conta que a norma deve intentar a proteção de interesses particulares contra determinados perigos, na sua hipótese normativa tipificados.

Ora, no caso concreto, parecem eles identificar-se, a par do interesse público na segurança rodoviária, com os interesses na incolumidade da integridade física e propriedade

conteúdo impositivo e/ou proibitivo deveria ser considerada lícita. Cremos não ser sustentável o segundo entendimento posto em diálogo. Duas razões apontam claramente no sentido do seu afastamento: a) aceitá-lo implicaria um reconhecimento de que o estrato normativo ditaria a relevância jurídica dos comportamentos, independentemente das exigências de sentido comunicadas por cada caso, aproximando-nos perigosamente de uma lógica positivista nos termos da qual o que não é proibido é permitido; b) em contravenção com a própria ideia do domínio ou predomínio sistemático, inverter-se-ia a relação hierárquica entre as hipóteses delituais básicas plasmadas pelo legislador.

${ }^{20}$ Nesse sentido, MONTEIRO, Sinde. Responsabilidade... p. 239. Refere o autor que nestes casos não se alarga a proteção de bens jurídicos que já resultava da primeira modalidade de ilicitude.

${ }^{21}$ Circunscrevemo-nos às duas modalidades básicas de ilicitude previstas expressamente no artigo $483^{\circ}$ CC. Desconsidera-se, portanto, a possibilidade de entrar em cena a responsabilidade objetiva pelos danos causados por um veículo automóvel.

${ }_{22}$ Cf. Sobre o ponto, cf. BARBOSA, Mafalda Miranda. Do nexo de causalidade ao nexo de imputação, p. $914 \mathrm{~s}$.

Revista IBERC, Minas Gerais, v. 2, n. 2, p. 01-38, mai.-ago./2019 


Revista IBERC
v. 2, n. 2, p. 01-38, mai.-ago./2019
www.responsabilidadecivil.org

dos utentes estradais. A norma vem tutelar uma zona específica do bem jurídico objeto de proteção pelo direito absoluto cuja violação tinha sido denotada ao abrigo da primeira modalidade de ilicitude delitual. Ou melhor, a disposição legal vem estabilizar um modo de evicção daquela posição subjetiva eficaz erga omnes que, exatamente por o ser, já era protegida em termos gerais. Há que, portanto, procurar a mais-valia da sobreposição denotada. Dir-se-á, como já se disse, que a culpa se refere exclusivamente à violação da norma, não tendo de ser previsível o resultado.

Só que, como bem nota Sinde Monteiro, não há aqui grande divergência em termos práticos, dado que "quem tem de prever o perigo concreto tem sempre de contar com a realização do resultado" 23 . Passaria, então, para o insigne civilista, a apurada compreensão do sistema pela dicotomização entre os delitos de perigo concreto e de perigo abstrato, posto que, nos segundos, "nem sequer é necessário que seja previsível a ocorrência de um dano", correspondendo a divisória à distinção entre as disposições de proteção em sentido amplo e em sentido estrito ${ }^{24}$.

Com o que também não se agigantariam as consequências prático-normativas, dado que não só a existência de qualquer dessas normas não conduz à redução do âmbito de proteção, mas tão-só ao seu alargamento ${ }^{25}$, como a estabilização legislativa de um comportamento tido por perigoso torna difícil a afirmação da não cognoscibilidade do resultado pelo lesante. Haveria para Sinde Monteiro um adiantamento da responsabilidade sempre que em causa estivesse a proibição de um pôr em perigo abstrato. Elas incluiriam "também justamente a falta de cognoscibilidade de um concreto pôr em perigo nas suas considerações

\footnotetext{
${ }^{23}$ Cf. MONTEIRO, Sinde. Responsabilidade ... p. 239.

${ }^{24}$ Cf. MONTEIRO, Sinde. Responsabilidade ... p. 240. A distinção, neste quadro, não é, porém, exclusiva do pensamento do civilista português (para quem só as normas de perigo abstrato são normas de protecção stricto sensu). Encontramo-la, também, inter alia, em VoN BAR, Christian. Verkehrspflichten, p. 286-287.

Note-se que, para Sinde Monteiro, a generalidade das normas do código penal, na medida em que protegem bens jurídicos coincidentes com os que, ao nível do direito civil, são tutelados por via de direitos absolutos, não seriam verdadeiras disposições de proteção em sentido estrito (a sua importância ficaria, pois, limitada ao facto de estabelecerem uma proibição de pôr em perigo concreto).

Quanto ao ponto, CORDEIRO, Menezes. Direito das Obrigações... p. 344 ss., incluindo na categoria as normas destinadas a proteger interesses pessoais como a vida, a honra, as normas de direito privado que tenham como intenção evitar violações de direitos e normas que, protegendo a coletividade, incluem a tutela do lesado; ALARCÃO, Rui de. Direito das Obrigações, p. 241 ss.

Veja-se, também, entre nós, LEITÃO. Normas de protecção...., p. 221, considerando que o § 823 II BGB só consegue atingir um campo de aplicação autónomo quando recorre a normas de conduta abstratas, como, por exemplo, a que proíbe circular a mais de $50 \mathrm{~km} / \mathrm{h}$ dentro das localidades.

Sublinhe-se, por isso, em abono do rigor, e na sequência do que ficou dito nesta nota que, não obstante o que dizemos em texto, o exemplo de que partimos neste pequeno excurso reporta-se a uma proibição de pôr em perigo abstrato.

${ }^{25}$ MONTEIRO, Sinde. Responsabilidade... p. 241-242.
}

Revista IBERC, Minas Gerais, v. 2, n. 2, p. 01-38, mai.-ago./2019 


\section{Revista IBERC}

v. 2, n. 2, p. 01-38, mai.-ago./2019

www.responsabilidadecivil.org

de proteção e impedem por isso o agente de invocar a falta de cognoscibilidade desse concreto pôr em perigo" ${ }^{26}$.

No que nos diz respeito, cremos não haver aí uma dessintonia latente. Na verdade, pode o agente, com o seu comportamento, apenas prever a violação da norma delitual, mas, ao fazê-lo, e porque a negligência se basta com a previsibilidade de um homem médio, não impondo que o agente tenha, de facto, previsto o resultado, não pode deixar de reconhecer a possibilidade de aquele sobrevir. Os delitos de perigo abstrato caracterizam-se pela inexigibilidade de verificação de um resultado. Mas, na mobilização civilística que destas normas se faça, porque consumada à luz das exigências que o caso, inteligido dialeticamente de acordo com um sistema privatístico que se pressupõe, parece esbater-se a anunciada diferença.

Em apreço, verdadeiramente, estaria a previsão, pelo legislador, de um comportamento perigoso e suscetível de pôr em causa determinados interesses polarizados num grupo delimitado de sujeitos particulares. Se em determinadas situações se basta com a censura dirigida à conduta, antecipando a proteção, noutras, exige-se um resultado, ainda que seja um puro pôr em perigo. Este, incorporado no âmbito normativo, faria parte do tipo, pelo que a norma vertida em disposição de proteção, uma vez violada, obviamente o incorporaria e, havendo culpa referida à preterição dela, o próprio resultado seria tido como culposo. Ou seja, violada a norma, o perigo concreto não pode deixar de ser reconhecido pelo agente. Outra seria a impostação do problema no caso de um pôr em perigo abstrato.

Uma linha divisória, aos nossos olhos, se impõe. Aquela que coloca, de um lado da fronteira, as disposições de proteção de interesses alheios distintos dos direitos subjetivos e, do outro, as que intentem tutelar interesses confluentes com essas posições dotadas de eficácia erga omnes ${ }^{27}$.

\footnotetext{
${ }_{27}^{26}$ MONTEIRO, Sinde. Responsabilidade... p. 244.

${ }^{27}$ Sobre o ponto, veja-se, igualmente, LEITÃO. Normas de protecção... p. 618 ss. A autora fala de dois núcleos distintos de normas de proteção: a) normas que se localizam no âmago de protecção dos direitos subjetivos, como seu complemento ou concretização, de que é exemplo a norma que proíbe a condução de veículos automóveis a uma velocidade superior a $50 \mathrm{~km} / \mathrm{h}$ nas localidades (teriam como vantagem o alargamento da ilicitude e do âmbito de proteção, permitindo um mais fácil preenchimento dos pressupostos da imputação delitual. Assim, segundo testemunha a autora, em consonância com a posição de outros juristas já por nós citados, a ilicitude cingir-se-ia à violação da norma, não ficando dependente da lesão do direito subjetivo, pelo que abrangeria o perigo de lesão do bem jurídico protegido - cf. p. 619; a culpa verter-se-ia num juízo de censura sobre aquela; a causalidade implica aferir se o resultado danoso se produziu no círculo de protecção da norma); b) normas que não se inserem no âmbito da protecção dos direitos subjetivos, mas permitem autonomizar a tutela de outros interesses.

Explicitemos o que, porventura, possa ter ficado implícito. O legislador consagra, no artigo $483^{\circ} \mathrm{CC}$ português, a possibilidade de se desvelar a ilicitude extracontratual por via da violação de disposições legais de proteção de interesses alheios. Saber o que elas são é matéria controversa, deixada ao labor jurisprudencial e doutrinal. Duas notas parecem, no entanto, prestimosas na orientação dessa tarefa. De um lado, a referência inolvidável ao carácter legal da disposição que se pretere; do outro, a proteção de
}

Revista IBERC, Minas Gerais, v. 2, n. 2, p. 01-38, mai.-ago./2019 


\section{Revista IBERC}

v. 2, n. 2, p. 01-38, mai.-ago./2019

www.responsabilidadecivil.org

É neste contexto que as normas da concorrência podem assumir importância extrema em termos delituais. Na verdade, a partir do momento em que possam ser qualificadas para os devidos efeitos como disposições legais de proteção de interesses alheios, é possível desvelarse, por meio da sua lesão, a ilicitude fundamentante de uma pretensão indemnizatória. A possibilidade foi, doutrinalmente, afirmada de forma detida e aprofundada, por Adelaide Menezes Leitão ${ }^{28}$, e jurisprudencialmente consagrada em decisões judiciais. Pensemos, no quadro do ordenamento jurídico alemão, cuja modelação não dista sobremaneira da do nosso em matéria delitual, o caso British Telecommunications plc. and Viag Interkom Gmbtt/Deutsche

interesses alheios, a chamar a atenção para a noção de interesse legalmente protegido que com o direito subjetivo estabelece uma relação de complementaridade e não de identidade, não havendo uma perfeita sinonímia, pois que a tutela erigida pelo segmento primeiro do artigo $483^{\circ}$ circunscreve-se aos direitos absolutos, enquanto aqui - nesta segunda modalidade de ilícito - se haverá de dar abertura à relatividade dos direitos dotados de eficácia inter partes. O legislador estabelecerá uma conduta proibida, a qual é erigida, embora não exclusivamente, para salvaguarda de interesses particulares. Para cumprir tal intenção prescritiva, pode optar por uma de duas vias. Considerar uma conduta proscrita, pela sua especial perigosidade, ou considerar que ela só deve ser considerada ilícita - independentemente do nicho dogmático em que se esteja mergulhado - quando haja um concreto pôr em perigo de determinados interesses. Neste caso, ao considerarmos que a culpa se refere à violação da norma, estamos, no fundo, a dizer que a culpa se há-de referir também a essa concreta colocação em risco, pelo que nenhuma dessintonia existe em relação à primeira modalidade de ilicitude delitual. Na primeira hipótese, o preenchimento da norma não envolve a previsão do resultado danoso. Mas não será legítimo que o homem medianamente sensato, prudente, razoável possa vir dizer que não previu o resultado danoso na situação concreta. Pois que, ao ser cristalizada a conduta por via normativa, tal implica que ela seja informada por um potencial danoso que tolhe a justificação aduzida.

Há uma antecipação da proteção, é certo, mas estamos em crer que ela não se projeta, em termos práticos, na exigência ou não de previsibilidade do resultado, dado ser esta implícita. Supomos antes que ela se agigantará naqueloutro problema da repartição do ónus da prova, pelo que, afinal, as duas questões, não sendo uma só, apresentam uma conexão estreita. Mais se diga que, a partir do momento em que o interesse protegido vem a desembocar num direito subjetivo absoluto, a segunda modalidade de ilicitude de que se fala passa a só ter interesse em matéria de determinação da forma de imputação. Posto isto, e no seguimento do que anteriormente tínhamos dito, sempre que assim seja não há propriamente uma autonomia valorativa da preterição normativa, mas uma diversa ordenação dos pressupostos de imposição de uma pretensão indemnizatória. Com as disposições em causa a transverterem-se em normas fixadoras de deveres de precaução.

Importa, ainda, não esquecer o entendimento acerca do polo de referência da culpa ao nível da primeira modalidade de ilicitude.

Cf., quanto ao ponto, LEITÃO. Normas de protecção..., p. 163 ss. A autora, procurando esclarecer qual o ponto de referência da culpa ao nível da segunda modalidade de ilicitude e atendo-se à análise da evolução doutrinal germânica na matéria, vem dizer que, „segundo a posição corrente, interessam só a previsibilidade e a evitabilidade do comportamento contrário à norma por o § 823 II não se referir a um resultado ilícito. Isto é equívoco na medida em que muitos tipos legais de muitas normas de referência pressupõem um resultado ou pelo menos um resultado de colocação em perigo. A culpa tem de se referir ao tipo legal, o que significa que o ponto de referência da culpa é a ilicitude. Em delitos de perigo abstracto, a culpa é de pressupor só em relação ao comportamento. O tipo legal não exige mais. Em sentido diferente, uma posição exige igualmente que a culpa abranja a violação dos interesses que fundamentam a responsabilidade. Esta solução equipara os pressupostos da culpa do $\S 823$ I e II BGB. A responsabilidade não se estendem a todas as consequências possíveis, mas só àquelas que resultam da violação do interesse imediatamente protegido“.

${ }^{28}$ LEITÃO. Normas de protecção... igualmente, CARAPINHA, Rui. O private enforcement do direito da concorrência à luz do direito português. Lisboa, 2014 e VASCONCELOS, Maria João Pestana de. Algumas questões sobre a ressarcibilidade delitual de danos puramente patrimoniais no ordenamento jurídico português. Novas tendências da responsabilidade civil, Almedina, p. 183 ss.

Revista IBERC, Minas Gerais, v. 2, n. 2, p. 01-38, mai.-ago./2019 


\section{Revista IBERC}

v. 2, n. 2, p. 01-38, mai.-ago./2019

www.responsabilidadecivil.org

Telekom, no âmbito do qual se considerou que poderia gerar-se responsabilidade extracontratual ao abrigo do $\S 823$ II BGB ${ }^{29}$.

Entre nós, são conhecidos alguns acórdãos na matéria ${ }^{30}$. Não são, porém, isentas de dificuldade as questões relacionadas com a invocação das normas concorrenciais para tutela de interesses individuais. Em muitos casos, denota-se uma certa ambivalência judicativa quer no tocante à possibilidade de se invocarem as referidas normas como disposições legais de proteção de interesses alheios, quer no tocante ao âmbito subjetivo de proteção que dispensam em concreto.

No acórdão de 20 de Junho de 2013, o Supremo Tribunal de Justiça admitiu a possibilidade de se mobilizarem as regras da concorrência no quadro da responsabilidade civil, considerando ao mesmo tempo que consumidores e empresas se enquadram no escopo de proteção da norma concretamente violada. No mesmo sentido, o Tribunal da Relação de Lisboa, no acórdão de 7 de Dezembro de 2012, considerou a viabilidade de uma indemnização por violação das normas da concorrência, decidindo pela integração de consumidores e concorrentes no âmbito de proteção da norma ${ }^{31}$. Parece denotar-se, por isso, uma mudança da perspetiva judicativa dos nossos tribunais superiores. Na verdade, em sentenças anteriores, o Supremo Tribunal de Justiça teria afastado a possibilidade de os lesados invocarem a proteção de normas de concorrência para obterem uma indemnização, por considerar que tais normas não conferem um direito subjetivo a essa tutela ${ }^{32}$. Neste segmento, a decisão do nosso tribunal superior não pode ser senão criticada: em causa não está, obviamente, o reconhecimento de um direito subjetivo, mas de um interesse que, integrando-se no âmbito de proteção da norma e sendo preterido, pode dar origem a uma pretensão indemnizatória.

O cerne da problemática, uma vez estabelecida a natureza de disposição de proteção das normas da concorrência, passa, portanto, pela delimitação do âmbito de proteção dessa mesma norma ou, e numa perspetiva mais abrangente, de estabelecer critérios de imputação que nos permitam delimitar a responsabilidade a este nível. É que a simples consideração dos concorrentes e consumidores, sem mais, poderá colocar-nos a dificuldade de fazer resvalar a responsabilidade para limites incomportáveis.

\footnotetext{
${ }^{29}$ WOODS, Donncadh; SINCLAIR, Alisa, ASHTON, David. Private enforcement of community..., p. 3.

30 Sobre o ponto, com grande importância, cf. ERRO, Miguel. Jurisprudência de private enforcement..., p.178 s.

${ }^{31}$ Sobre estes casos, com uma análise pormenorizada deles, FERRO, Miguel. Jurisprudência de private enforcement..., p. 188 ss.

32 Trata-se do acórdão do STJ de 21 de Março de 1996, mencionado e comentado por FERRO, Miguel. Jurisprudência de private enforcement..., p. 185 ss. Veja-se, também, o acórdão do STJ de 21 de Outubro de 2010 , onde se considera que não há possibilidade os lesados invocarem as normas da concorrência para obterem uma indemnização, mas, segundo o parecer de Miguel Ferro, onde parece sugerir-se que os consumidores poderiam invocar as normas da concorrência para obter o ressarcimento.
}

Revista IBERC, Minas Gerais, v. 2, n. 2, p. 01-38, mai.-ago./2019 


Revista IBERC
v. 2, n. 2, p. 01-38, mai.-ago./2019
www.responsabilidadecivil.org

O que assim fica dito percebe-se claramente: lidamos a este nível com danos puramente patrimoniais, o que significa que não nos devemos deixar de preocupar com a contenção da indemnização, já que estes, pela sua própria natureza, podem estender-se ao infinito. Por outro lado, se recusamos a sua indemnização de princípio, para a afirmarmos em todos os casos em que exista a violação de uma disposição legal de proteção de interesses alheios, então isso significa que só estamos legitimados a ir até onde nos permita a intencionalidade normativa da norma que, a este ensejo, modelará a responsabilidade.

Uma conclusão é, independentemente das questões dogmáticas a que aludimos, inegável: o ordenamento jurídico português reconhece a importância dos interesses privados subjacentes às normas de direito da concorrência. Este reconhecimento parece, aliás, existir igualmente nos restantes ordenamentos jurídicos da nossa zona de influência. Isso mesmo se denota pela análise dos projetos europeus de harmonização do direito delitual. Não procurando afirmar-se como um instrumento normativo com força vinculativa, tais projetos acabam por funcionar como uma solução de compromisso que refletem as diversas posições dos ordenamentos europeus, constituindo, nessa medida, como um instrumento útil de direito comparado. Ora, no artigo 2:208 do livro VI do Draft Common Frame or Reference podemos ler que o dano causado a um consumidor como resultado de concorrência desleal é um dano legalmente relevante se o direito nacional ou comunitário o prever.

\section{A LEI No 23/2018, DE 5 DE JUNHO}

Fruto da necessidade de transposição da Diretiva 2014/104/EU, o legislador português aprovou recentemente, através da Lei $n^{\circ} 23 / 2018$, de 5 de Junho, o regime do private enforcement da concorrência. Em rigor, foi-se mais longe do que aquilo que era imposto pela diretiva, porque, para além de a ação de indemnização poder ser fundada na violação do direito comunitário da concorrência, admite-se a possibilidade de se alicerçar na preterição de regras da concorrência que não convoquem a aplicação do quadro normativo comunitário ${ }^{33}$.

${ }^{33}$ A este propósito, considera Miguel Gorjão Henriques que a disciplina se estende às ações de indemnização por violação dos artigos $9 .^{\circ}$ e/ou $11 .^{\circ}$ do RJC que não convoquem a aplicação do direito da União Europeia. Mas admite que o regime se possa aplicar a ações de indemnização que tenham como causa de pedir outras infrações ao direito da concorrência nacional previstas no RJC ou mesmo outras infrações ao direito da concorrência da UE. Entre as primeiras, contam-se as ações de indemnização por violação do artigo $12 .^{\circ}$ (abusos de dependência económica), mas também as ações de indemnização derivadas, por exemplo, de danos sofridos por ilegalidades cometidas pela própria Autoridade da Concorrência $(\mathrm{AdC})$ - como por exemplo, arquivamentos ilícitos de denúncias - ou por empresas, e por danos danos resultantes de violações do dever de notificação prévia de concentrações de empresas. Entre as segundas, encontram-se as ações de indemnizações por danos sofridos por força de auxílios

Revista IBERC, Minas Gerais, v. 2, n. 2, p. 01-38, mai.-ago./2019 


\section{Revista IBERC}

v. 2, n. 2, p. 01-38, mai.-ago./2019

www.responsabilidadecivil.org

O regime em questão introduz regras especiais num domínio específico de responsabilidade civil. Nem por isso se pode concluir pela introdução de uma disrupção no sistema. Pelo contrário, o artigo $3^{\circ}, \mathrm{n}^{\circ} 1$, remete expressamente para o citado artigo $483^{\circ} \mathrm{CC}$. Não obstante, haveremos de ser particularmente cuidadosos na interpretação das diferentes soluções para que não se abra por esta via as portas a situações de hiper-responsabilidade.

Estabelece o artigo $3^{\circ}, n^{\circ} 1$, Lei $n^{\circ} 23 / 2018$ que «a empresa ou associação de empresas que cometer uma infração ao direito da concorrência fica obrigada a indemnizar integralmente os lesados pelos danos resultantes de tal infração, nos termos previstos no artigo 483. ${ }^{\circ}$ do Código Civil». A hipótese agora consagrada neste artigo $3^{\circ}$ não acrescenta, portanto, mais do que aquilo que já decorreria do funcionamento do sistema delitual ${ }^{34}$. Mas nem por isso nos resolve todos os problemas. Embora fiquemos esclarecidos no tocante à natureza das normas concorrenciais, que podem, de facto, ser qualificadas como disposições legais de proteção de interesses alheios, não nos são oferecidos critérios de delimitação da responsabilidade afirmada.

O cerne da problemática passa, portanto, a ser o da circunscrição do âmbito de proteção das referidas normas ou, e numa perspetiva mais abrangente, o de estabelecer critérios de imputação que nos permitam delimitar a responsabilidade a este nível. Se o nosso legislador, na transposição da Diretiva, não nos ofereceu critérios suficientemente precisos de limitação das pretensões indemnizatórias, isto significa que valem aqui as regras em matéria de responsabilidade civil extracontratual, fundada na segunda modalidade de ilicitude (violação de disposições legais de proteção de interesses alheios), para a qual, aliás, somos agora expressamente remetidos.

Têm direito a uma pretensão indemnizatória todos aqueles que se incluam no âmbito de proteção da norma, cumpridos que estejam os critérios de imputação objetiva (ao nível do que se designa por causalidade fundamentadora da responsabilidade) no caso concreto. Ao violar as relevantes normas da concorrência, o agente do mercado (empresa) assume uma esfera de risco/responsabilidade, devendo responder por todos os danos que se liguem funcionalmente àquela infração, que são, exatamente, aqueles que se pretendiam obviar com a

públicos ilegais e/ou incompatíveis com o mercado interno - para um confronto com esta posição de Miguel Gorjão Henriques, CAPELO, Maria José; BARBOSA, Mafalda Miranda; HENRIQUES, Miguel Gorjão. Private Enforcement do direito da concorrência. Comentário à Lei $n^{\circ} 23 / 2018$, de 5 de Junho, ainda em elaboração. Devem-se ao autor as anotações referentes ao direito da concorrência.

${ }^{34}$ Isto não quer dizer que o regime do private enforcement da concorrência não introduza regras especiais em relação ao regime geral da responsabilidade civil. Significa sim que continua a haver linhas de continuidade entre o regime especial e o regime geral e que este, com os seus quadros dogmáticos, haverá de funcionar como subsidiário daquele.

Revista IBERC, Minas Gerais, v. 2, n. 2, p. 01-38, mai.-ago./2019 


\section{Revista IBERC}

v. 2, n. 2, p. 01-38, mai.-ago./2019

www.responsabilidadecivil.org

adoção do comportamento lícito. No mais, existindo um regime especial, importa questionar quem pode vir a ser por ele responsabilizado.

Três são, então, os segmentos problemáticos com que temos de lidar, um subjetivo e outro objetivo. Dito de outro modo, haveremos de saber quem pode exigir uma indemnização (âmbito de tutela subjetivo), por que danos (âmbito de tutela objetivo) e de quem (quem é responsável).

\subsection{Quem é responsável?}

Baseando-se a responsabilidade com que estamos a lidar na violação das regras da concorrência, é fácil de perceber que o responsável é aquele que violar a norma em apreço. Podem, assim, ser responsabilizados, nos termos da Lei $n^{\circ}$ 23/2018, a empresa ou associação de empresas que cometam uma infração ao direito da concorrência. Nos termos do artigo $3^{\circ} / 2$ Lei $n^{\circ} 23 / 2018$, é ainda responsável a pessoa ou pessoas que tenham exercido influência determinante, nos termos do artigo 36\%3 Lei $n^{\circ} 19 / 2012$, de 8 de Maio, durante a infração, sobre a infratora. Na Proposta de Lei aprovada pelo Governo, bem como no Anteprojeto elaborado pela Autoridade da Concorrência dispunha-se que quando uma empresa incluísse uma pluralidade de pessoas coletivas, a atuação de uma pessoa é igualmente imputável à pessoa ou pessoas que sobre ela exercessem influência determinante.

$\mathrm{Na}$ versão final do diploma, ao dispor-se, como se referiu, que «é igualmente responsável pela obrigação de indemnização prevista no número anterior a pessoa ou pessoas que tenham exercido influência determinante, nos termos do n. 3 do artigo $36 .^{\circ}$ da Lei n. ${ }^{\circ}$ 19/2012, de 8 de maio, durante a infração sobre a infratora», somos claramente remetidos para o âmbito da concentração de empresas, a implicar uma mudança duradoura de controlo sobre a totalidade ou parte de uma ou mais empresas, em resultado da fusão de duas ou mais empresas ou partes de empresas anteriormente independentes ou da aquisição, direta ou indireta, do controlo da totalidade ou de partes do capital social ou de elementos do ativo de uma ou de várias outras empresas, por uma ou mais empresas ou por uma ou mais pessoas que já detenham o controlo de, pelo menos, uma empresa. No que respeita à influência determinante, ela pode traduzir-se, designadamente, na aquisição da totalidade ou de parte do capital social; na aquisição de direitos de propriedade, de uso ou de fruição sobre a totalidade ou parte dos ativos de uma empresa; ou na aquisição de direitos ou celebração de contratos que confiram uma influência determinante na composição ou nas deliberações ou decisões dos órgãos de uma empresa.

Revista IBERC, Minas Gerais, v. 2, n. 2, p. 01-38, mai.-ago./2019 


\section{Revista IBERC}

v. 2, n. 2, p. 01-38, mai.-ago./2019

www.responsabilidadecivil.org

Mas, independentemente dos aspetos especificamente concorrenciais aqui chamados à colação, é bom de notar que se trata de uma solução que nos aponta, claramente, para uma ideia de imputação: não se responsabiliza, apenas, aquele que protagoniza a conduta geradora do dano, mas todas as outras pessoas coletivas que sobre ela exerçam uma influência determinante. A solução está em consonância com os mais recentes desenvolvimentos da doutrina, em matéria de causalidade ao nível da responsabilidade civil. De facto, ela mostranos que já não se indaga qual a causa do dano (o que nos remeteria para critérios naturalistas, ainda que normativizados, assentes no cálculo de probabilidades, típico do juízo de prognose póstuma da causalidade adequada), mas que se questiona a quem ele deve ser imputado.

$\mathrm{Na}$ resposta que se encontre para o problema podemos, assim, deixar de responsabilizar (ou deixar de responsabilizar só) o agente que materialmente causa o dano, para responsabilizarmos (ou responsabilizarmos também) os que, detendo uma esfera de risco (edificada pela especial posição que ocupam na situação controvertida ou pela preterição de determinadas regras de cuidado que, ao mesmo tempo, viabilizam um juízo de censura éticojurídica em que se traduz a culpa e lançam as bases para uma prévia sindicância acerca da imputação objetiva), não a veem ser consumida pela esfera de responsabilidade edificada pelo outro sujeito.

No fundo, e no tocante à violação de regras da concorrência, o legislador vem consagrar uma ideia imputacional muito próxima da intencionalidade que preside à melhor solução genérica em matéria de responsabilidade civil. De facto, existindo uma pessoa coletiva que exerce sobre outra uma influência determinante, o comportamento dessa outra deixa de ser o ponto exclusivo da imputação delitual. Note-se que, para que possa haver imputação à pessoa coletiva sobre a qual é exercida uma influência determinante, o seu comportamento tem de ser livre. Não o sendo, deixa de ser possível a imputação (por se perder o requisito mínimo que viabiliza a operacionalidade da categoria), considerando-se que tal sujeito funciona, afinal, como a longa manus da atuação da outra pessoa coletiva.

Fundamental é, neste ensejo, esclarecer o que é a influência determinante. $O$ conceito, percetível do ponto de vista civilística à luz da teoria imputacional que se esboça em traços largos, exige que se convoquem noções próprias de direito da concorrência. A este respeito, o Tribunal de Justiça tem salientado que a "influência determinante" presume-se existir quando «uma sociedade-mãe detém a totalidade ou a quase totalidade do capital da sua filial que cometeu uma infração às regras de concorrência da União», presunção de exercício 


\section{Revista IBERC}

v. 2, n. 2, p. 01-38, mai.-ago./2019

www.responsabilidadecivil.org

de uma influência determinante que é, no entanto, uma mera "presunção ilidível", iuris tantum ${ }^{35}$. Os critérios constam do citado artigo $36 \% 3$ Lei n 19/2012, mas a solução não está isenta de dificuldades a outros níveis.

$\mathrm{Na}$ discussão sobre o Anteprojeto da Gesetz gegen Wettbewerbsbeschränkungen (GWB), na Alemanha, a questão foi amplamente considerada, não tendo, contudo, obtido uma resposta contundente. O legislador germânico, amparado pela doutrina, mostrou-se reticente quanto à questão da responsabilização de uma empresa pela violação do direito da concorrência cometida por uma subsidiária, por se temer que a afirmação dessa responsabilidade pudesse ter repercussões noutros domínios do direito civil alemão, designadamente ao nível societário onde, em regra, se proíbe a desconsideração da personalidade jurídica das pessoas coletivas, o que leva a que os membros de um grupo não possam ser responsabilizados pelos atos de outro. Nessa medida, a tomada de posição acerca da questão foi remetida para o prudente arbítrio do julgador.

De todo o modo, o legislador germânico mostra-se, quanto ao ponto, ambíguo, uma vez que previu a responsabilidade da empresa-mãe por multas, excluindo, contudo, a esse nível, a responsabilidade das «empresas-filiais», na medida em que não estabeleceu a responsabilidade do grupo como um todo ${ }^{36}$. Muitos foram os argumentos avançados no sentido da não responsabilização do "grupo" (ou seja, das filiais) ou mesmo da empresa dominante. Contudo, consonante explicita Christian Kersting, essa responsabilidade parece não só ser imposta pela Diretiva, como estar em linha com o que vem sendo entendido pelas instâncias comunitárias. Acresce que não haveria qualquer contradição com o direito societário, uma vez que uma empresa mãe não é responsabilizada como participante da violação da sua filial, mas como parte de uma unidade económica que cometeu a violação como um todo ${ }^{37}$.

\subsection{Por que danos?}

Como regra, podemos afirmar que o infrator da norma da concorrência é responsável por todos os danos que poderiam ser obviados se não tivesse sido cometida a infração. Não nos podemos, contudo, ater a uma estrutura linear da imputação, que nos oriente apenas por

\footnotetext{
${ }^{35}$ Acórdão do Tribunal de Justiça de 27.4.2017, Akzo Nobel NV e outros c. Comissão Europeia, proc. C516/05 P, EU:C:2017:314, n. 54-56. A este propósito, cf., novamente, a posição de Miguel GorjãoHenriques, no texto citado, que oportunamente será publicado.

${ }^{36}$ Sobre o ponto, KERSTING, Christian. Transposition of the antitrust damage directive into German Law. The EU Antitrust Damages Directive: Transposition in the Member States, Oxford University Press, 2017. Disponível em: https://papers.ssrn.com/sol3/papers.cfm?abstract_id=2998586. Acesso em 07 mai. 2019.

${ }^{37}$ KERSTING, Christian. Transposition of the antitrust..., p. 07 ss.
}

Revista IBERC, Minas Gerais, v. 2, n. 2, p. 01-38, mai.-ago./2019 


\section{Revista IBERC}

v. 2, n. 2, p. 01-38, mai.-ago./2019

www.responsabilidadecivil.org

esta ligação entre o dano concretamente verificado e a violação normativa. Há, na verdade, que solucionar, a montante, o problema da fundamentação da responsabilidade, isto é, da ligação entre o comportamento do sujeito e a violação do interesse subjacente à norma, por um lado, e, a jusante, o problema do seu preenchimento, ligando a violação do interesse aos danos subsequentes.

Ao violar uma disposição legal de proteção de interesses alheios, o sujeito assume uma esfera de risco/responsabilidade, sendo-Ihe imputáveis as lesões dos interesses que se inscrevessem na teleologia da norma. Mas tal não é bastante.

Desde logo, torna-se particularmente relevante a problematização do comportamento lícito alternativo. Em termos práticos, não há unanimidade no tocante ao significado da invocação de um comportamento lícito alternativo. Se muitos advogam a sua procedência, baseando-se para o efeito na ideia de que, nestes casos, a ilicitude não teria cumprido a sua verdadeira função como elemento crucial de edificação do dever de indemnizar, outros parecem remeter a relevância dele para o âmbito da finalidade de proteção da norma, ficando a solução concreta dependente desse escopo. Seja como for, e independentemente das posições particulares que vão sendo firmadas, descontadas as tentativas de abordagem do tema à lupa da causalidade hipotética, é na ligação ao requisito da ilicitude que se joga o cerne da problemática.

E por isso entende-se que, ultrapassada a visão mais ortodoxa dela, a sua mobilização surja com particular acuidade ao nível da segunda modalidade de ilicitude. A descoberta da falta de relevância da norma violada para a emergência do dano vem mostrar, afinal, que a intencionalidade normativa do caso não é assimilada pela intencionalidade normativa daquela. Do que se trata é de saber se o dano teria tido lugar sensivelmente do mesmo modo, no mesmo tempo e nas mesmas condições ainda que a preterição do dever não se tivesse verificado. Ou dito de outro modo, pergunta-se em que medida a conduta conforme ao direito teria diminuído de forma significativa o risco de realização do evento lesivo, quebrando-se, em caso de resposta afirmativa, o nexo de ilicitude que se começava a desenhar com a violação normativa ${ }^{38}$, porque o que essa resposta indicaria seria a irrelevância da norma para obviar a lesão que acabou por ocorrer.

38 A propósito do comportamento lícito alternativo, cf. inter alia, LANGE, Hermann; SCHIEMANN, Gottfried. Handbuch des Schuldrechts - Schadensersatz. 3. Auflage, Tübingen: Mohr, 2003. p. 199; LARENZ,Karl. Lehrbuch des Schuldrechts - Allgemeiner Teil. Band 1, 14 Auflage, München: Verlag C. H. Beck, 1987, p. 527 ss.; LARENZ. Präventionsprinzip und Ausgleichsprinzip im Schadensersatzrecht. Neue Juristische Wochenschrift, 59, p. 865 ss.; MEDICUS, Dieter. Bürgerliches Recht. 21 Auflage, Köln: Carl Heymanns Verlag, 2007, p. 543 ss.; JANSEN, Nils. Digest Essential Cases on Natural Causation: 1 (Digest of European Tort Law), Springer-Verlag KG, 2007, p. 13 (comentários a Oberster Gerichtshof Bayern, 29 de Agosto de 1818; 9 de Março de 1838; 8 de Janeiro de 1845); ZIMMERMANN, R.;

Revista IBERC, Minas Gerais, v. 2, n. 2, p. 01-38, mai.-ago./2019 


\section{Revista IBERC}

v. 2, n. 2, p. 01-38, mai.-ago./2019

www.responsabilidadecivil.org

Em segundo lugar, haveremos de fazer dialogar a esfera de risco que assim se desenha (a partir da preterição do comando normativo) com a esfera de risco geral da vida, com a esfera de risco do lesado e a esfera de risco de terceiros, para perceber em que medida alguma delas exerce ou não uma força consumptiva sobre a primeira. Isto permite-nos antever que não serão indemnizáveis todos e quaisquer danos, mas apenas aqueles que se unam à infração cometida por um nexo de ilicitude assim desenhado.

Paralelamente a este segmento de fundamentação da responsabilidade, teremos de lidar com o seu preenchimento. É inerente ao direito subjetivo absoluto um dado conteúdo patrimonial, traduzível numa nota de utilidade. Sempre que ela não possa ser realizada, fruto da intervenção de um estranho à esfera de domínio traçado pelo direito, desenha-se um dano. Este importa a consideração da repercussão que a lesão teve, já não no titular abstratamente configurado, mas na esfera da pessoa realmente lesada, uma vez que esse impacto é variável.

Imageticamente, podemos configurar duas esferas. Uma esfera de utilidade geral traduzida no valor patrimonial do bem objeto do direito e, mais especificamente, compreendida pela análise das diversas faculdades inerentes ao conteúdo do direito - e uma esfera de utilidade particular - colimada naquilo que o concreto titular da posição subjetiva absoluta, dentro do primeiro círculo definido, se propõe realizar. Com base no cotejo destas duas esferas

KLEINSCHMIDT, J., Digest..., p. 16 ss. (comentário a Bundesgerichtshof, 24 Outubro de 1985); DEUTSCH. Allgemeines Haftungsrecht. 2. völlig neugestaltete end erw. Auflage, Köln: Carl Heymanns, 1996, 122; KOZIOL, Helmut. Rechtsmäßiges Alternativverhalten- Auflockerung starrer Lösungsansätze. Festschrift für E. Deutsch zum 70. Geburtstag, AHRENS, H. J.; VON BAR, Christian; SPICKHOFF, A.; TAUPITZ, J. (Hrsg.), Köln: Heymann, 1999. p. 179 s.; VON CAEMmERER. Das Problem der überholenden Kausalität im Schadensersatzrecht. Gesammelte Schriften, Band I, 1962, p. 445 ss.; GOTZLER, Max. Rechtsmässiges Alternativverhalten im haftungsbegründenden Zurechnungszusammenhang. München: Beck, 1977, p. 22 ss; ESSER; SCHMIDT. Schuldrecht - Allgemeiner Teil. Band I, Teilband 1, 8. Auflage, 1995; Teilband 2, 8. Auflage, Heidelberg: C. F. Müller, 2000, p. 539 ss.; MONTIJANO, Martín GarcíaRipoll. Imputación objetiva, causa próxima y alcance de los daños indemnizables. Granada: Editorial Comares, 2008, p. 182 ss.; DÍEZ-PICAZO. Derecho de daños. Madrid: Civitas, 1999, p. 348 ss.; GRUNSKY, Wolfgang. Rezension: Max Gotzler, Rechtsmäßiges Alternativverhalten im haftungsbegründenden Zurechnungszusammenhang. Archiv für die civilistische Praxis, 178, Heft 2/3, 1978, p. 330 ss.; FIKENTSCHER; HEINEMANN. Schuldrecht. 10 Auflage, Berlin: De Gruyter, 2006, p. 343; HANAU. Die Kausalität der Pflichtwidrigkeit: eine Studie zum Problem des pflichtmässigen Alternativverhaltens im bürgerlichen Recht. Göttingen: Schwartz, 1971, p. 35 ss.; HARKE, Jan Dirk. Allgemeines Schuldrecht. Heidelberg-Berlin: Springer, 2010. p. 295; WESTERMANN; BYDLINSKI; WEBER. BGB - Schuldrecht Allgemeiner Teil. 6. neu bearbeitete Auflage, Heidelberg: C.F. Müller, 2007, p. 247 ss., VIEWEG, Klaus. Schadensersatezrecht. J. Von Staudinger Kommentar zum BGB. 13. Auflage, Berlin: De Gruyter, 2005, p. 393; WISSMANN. Die Berufung auf rechtsmässiges Alternativverhalten. Neue Juristische Wochenschrift, 71, p. 549 ss.; DEUTSCH; AHRENS. Deliktrecht, Unerlaubte Handlungen, Schadensersatz und Schmerzensgeld. 4. Auflage, Köln: Carl Heymanns Verlag, 2002, p. 37 s. Entre nós, MONTEIRO, Sinde. Définition de la causalité: la causalité dans les projets nationaux. Disponível em : http://grerca.univ-rennes1.fr/digitalAssets/267/267958_jsmonteiro.pdf. Acesso em 17 mai. 2019; MONTEIRO, Sinde. Sobre uma eventual definição da causalidade nos projectos nacionais europeus de reforma da responsabilidade civil. Revista de Direito do Consumidor, Revista dos Tribunais, vol. 20, n. 78, 2011, p. 161-188; MONTEIRO, Sinde. Responsabilidade... p. 286-ss.; BARBOSA, Mafalda Miranda. Do nexo de causalidade... p. 940 ss. Sobre estas conclusões, veja-se, ainda, BARBOSA, Mafalda Miranda. Private enforcement... p. 278 ss.

Revista IBERC, Minas Gerais, v. 2, n. 2, p. 01-38, mai.-ago./2019 


\section{Revista IBERC}

v. 2, n. 2, p. 01-38, mai.-ago./2019

www.responsabilidadecivil.org

podemos encontrar a essência do que é o dano. E mais do que encontrar a essência do que é o dano ${ }^{39}$, podemos encontrar aqui um critério de recondução dos danos subsequentes - dos segundos danos - ao dano evento (dano primário ou violação do direito subjetivo que, ao nível da primeira modalidade de ilicitude, assume uma posição charneira em toda a questão imputacional) ${ }^{40}$.

A partir dele conseguimos, de facto, saber em que medida o que a pessoa perdeu ou aquilo que deixou de ganhar se inscreve ou não na esfera do direito cuja lesão já tinha sido imputada a um determinado sujeito ${ }^{41}$. O mesmo raciocínio se pode fazer por referência aos interesses lesados, quando protegidos por disposições legais de proteção de interesses alheios. O dano há-de, aí, ser compreendido como a repercussão negativa da preterição daquele interesse. A questão que nos orientará é: o que é que o ordenamento jurídico faculta ao sujeito quando o protege naquele interesse? O dano será oferecido como o reverso desse interesse.

Estando em causa, como estão, puros interesses patrimoniais, parece que a estrutura normativa da norma faz esbater (ou pode fazer esbater) a cisão entre a causalidade fundamentadora e a causalidade preenchedora da responsabilidade, sem que a apague. Ao determinar que a preterição do interesse deve ser reconduzida ao comportamento proibido por lei e protagonizado pelo lesante, estamos a considerar, simultaneamente, quais os danos que se indemnizam. De certo modo, a recondução do dano à lesão do interesse (em termos de imputação objetiva) estabelece-se, no caso concreto, paredes-meias com a questão da recondução da lesão do interesse à preterição da norma. A ponderação de eventuais causas alternativas dá-se no momento do juízo imputacional estabelecido a montante, enquanto nexo de ilicitude que se tem de erigir.

A este propósito, torna-se particularmente relevante o $n^{\circ} 1$ do artigo $9^{\circ}$ Lei $n^{\circ} 23 / 2018$, segundo o qual "os cartéis são responsáveis pelos danos causados pelas infrações que pratiquem, salvo prova em contrário». Significa isto que o lesado terá de provar a existência de danos (v.g. o aumento dos preços) e que, uma vez alegada e comprovada a sua emergência, se considera que os cartéis são por eles responsáveis, quando resultem das infrações ao

\footnotetext{
${ }^{39}$ CARNELUTTI. II danno e il reato. Padova: Cedam, 1929. p. 256 ss., afirmando que o dano não atinge o bem em si, mas a conexão da pessoa com o bem, ou seja, a relação existente entre um sujeito que tem uma necessidade e o bem apto a satisfazê-la.

${ }^{40}$ Assim se explica que o titular do direito à indemnização seja o titular do direito violado. Há, porém, exceções. Pense-se no artigo 495\%3 CC português. O dano indemnizável é aí correspondente ao montante da obrigação de alimentos que deixou de ser cumprida.

${ }^{41}$ Sobre o ponto, BARBOSA, Mafalda Miranda. Do nexo de causalidade... Cap. X; BARBOSA, Mafalda Miranda. Haftungsbegründende kausalität e haftungsausfüllende kausalität - Causalidade fundamentadora e causalidade preenchedora da responsabilidade. Revista da Faculdade de Direito e Ciência Política da Universidade Lusófona do Porto, n. 10, 2017, p. 14-36.
}

Revista IBERC, Minas Gerais, v. 2, n. 2, p. 01-38, mai.-ago./2019 


\section{Revista IBERC}

v. 2, n. 2, p. 01-38, mai.-ago./2019

www.responsabilidadecivil.org

direito da concorrência que cometeram. Presume-se, portanto, que os cartéis causam danos (como aliás decorre do artigo $17^{\circ}$ Diretiva) e que, quando estes se inscrevam no âmbito de proteção da norma de concorrência preterida, foram efetivamente provocados por eles. No fundo, deixa de se presumir o dano - que terá de ser provado pelo lesado, na sua existência, mas não na sua extensão (cf. o $n^{\circ} 2$ do artigo $9^{\circ}$ ) - para se passar a presumir o nexo de causalidade ou nexo de imputação entre a cartelização e os prejuízos advindos. Esta presunção é passível de prova em contrário.

Não basta, contudo, a prova de um mero percurso causal alternativo ou da existência de circunstâncias diversas daquelas que ocorrem numa hipótese de cartelização, exigindo-se a prova da real causa do dano. A solução consagrada na versão final do diploma afigura-se preferível àquela com que nos confrontávamos no anteprojeto da Autoridade da Concorrência e na Proposta de Lei aprovada pelo Governo, com base naquele. De facto, o artigo 9\%1 do Anteprojeto previa que os cartéis causam danos. No entanto, excluía-se a presunção de causalidade, que deveria ser provada pelo lesado.

A disciplina que resulta da lei suscitava-nos diversas críticas. Em primeiro lugar, importava sublinhar que não se prescindia do dano, que continuava presente como requisito imprescindível da imputação delitual, embora deixasse de se ter de provar a sua existência, que resultava presumida. Em segundo lugar, não se percebia como se presumia o dano, sem que concomitantemente se presumisse a causalidade. Se mesmo de um ponto de vista tradicional essa cisão se realizaria dificilmente, a partir do momento em que o juízo dito causal se perspetiva em termos normativos, ela deixava definitivamente de ser pensável.

Na verdade, ao presumir um dano, o legislador presume, também, o potencial danoso do comportamento e concomitantemente pressupõe que o sujeito titula uma esfera de risco a partir da qual é possível o surgimento daquele prejuízo. Ora, se assim é, não há como não presumir o próprio nexo de imputação (outrora visto como causalidade). Aliás, em rigor, aceite que seja uma visão personalista da causalidade, o problema da prova passa a ser encarado noutros moldes. Em geral, segundo defendemos a outro propósito, o lesado tem de provar a edificação de uma esfera de risco e a existência do evento lesivo.

O juízo acerca da pertença deste àquela esfera traduzir-se-á numa dimensão normativa da realização judicativo-decisória do direito. No fundo, provada a violação da norma da concorrência relevante para estes efeitos, presumido o dano, o lesado terá de provar simplesmente que se integra entre aqueles que a norma visava tutelar. A versão final do diploma resolve estes problemas e oferece-nos uma perspetiva imputacional de compreensão do nexo de causalidade, importando, contudo, sublinhar que, pelo modo como o problema deve ser compreendido em geral, não temos de ficar restringidos às hipóteses de cartelização.

Revista IBERC, Minas Gerais, v. 2, n. 2, p. 01-38, mai.-ago./2019 


\section{Revista IBERC}

v. 2, n. 2, p. 01-38, mai.-ago./2019

www.responsabilidadecivil.org

\subsection{Em relação a quem?}

Impõe-se, ainda, a descoberta dos sujeitos (e respetivos interesses) que se integram no âmbito de proteção da norma violada, como referido anteriormente ${ }^{42}$.

Importa, por isso, estar ciente do que efetivamente constitui uma infração da concorrência, nos termos do artigo $2 .^{\circ}$, alínea I). Em suma, devemos considerar que, verificando-se uma infração da concorrência sempre que sejam preteridas as normas dos artigos $9 .^{\circ}, 11 .^{\circ}$ e $12 .^{\circ}$ da Lei $.^{\circ} 19 / 2012$, de 8 de maio, dos artigos $101 .^{\circ}$ e $102 .^{\circ}$ do TFUE, apenas haverá direito à indemnização por parte daqueles que diretamente se integram no âmbito de proteção da norma. A disposição legal de proteção de interesses alheios concretamente violada visa tutelar o mercado, os consumidores, os fornecedores, os clientes e outros sujeitos.

Mas, porque a este nível apenas nos importam os interesses de pessoas determinadas ou grupos determinados de pessoas, só podem ser credores de uma indemnização os concorrentes no mercado, os clientes e os fornecedores do infrator. Não são tutelados a este nível os consumidores potenciais (todos nós), mas apenas os consumidores efetivos (que, efetivamente, tenham assumido uma relação de consumo), do mesmo modo que não são tutelados os potenciais concorrentes, mas apenas aqueles que atuem no mercado ou que tenham praticado atos preparatórios de atuação no mercado e vejam agravada a sua posição pelos concorrentes.

Problema particularmente interessante é o da tutela dos clientes indiretos e dos fornecedores indiretos. A possibilidade é aberta pelo artigo $8^{\circ}$ Lei $n^{\circ} 23 / 2018$.

O artigo $8 .^{\circ}, n .^{\circ} 1$, estabelece que, nas ações de indemnização, o réu (lesante) pode invocar como meio de defesa o facto de o autor (lesado) ter repercutido total ou parcialmente

\footnotetext{
${ }^{42}$ A perspetiva aqui assumida está defendida, para a responsabilidade civil em geral, em BARBOSA, Mafalda Miranda. Do nexo de causalidade..., em especial cap. 8 e em BARBOSA, Mafalda Miranda. Responsabilidade Civil extracontratual: novas perspetivas acerca do nexo de causalidade, Princípia, 2014. Não correspondendo à posição tradicional da doutrina em matéria de nexo de causalidade, ela tem vindo a ser acolhida pela jurisprudência dos tribunais superiores. Se em alguns acórdãos, a adesão é apenas à ideia da necessária compreensão do problema em termos imputacionais, noutros adere-se explicitamente ao entendimento das esferas de risco. Cf., inter alia, Acórdão Tribunal da Relação de Guimarães a 27 de Fevereiro de 2014, www.dgsi.pt; Acórdão Tribunal da Relação de Coimbra de 29 de Maio de 2012, www.dgsi.pt; Acórdão Supremo Tribunal de Justiça de 30 de Setembro de 2014, www.dgsi.pt; Acórdão Tribunal da Relação de Coimbra, de 13 de Maio de 2014, www.dgsi.pt; Acórdão Supremo Tribunal de Justiça 16 de Setembro de 2015, www.dgsi.pt; Acórdão Supremo Tribunal de Justiça de 7 de Março de 2017, www.dgsi.pt; Acórdão Supremo Tribunal de Justiça de 7 de Maio de 2014, www.dgsi.pt. Com especial importância, cf., igualmente, Acórdão Supremo Tribunal de Justiça de 19 de Maio de 2015, www.dgsi.pt; Acórdão Tribunal da Relação de Coimbra de 5 de Maio de 2015, www.dgsi.pt; Acórdão Supremo Tribunal de Justiça 16 de Setembro de 2015, www.dgsi.pt; Acórdão Tribunal da Relação do Porto de 11 de Setembro de 2017, www.dgsi.pt.
}

Revista IBERC, Minas Gerais, v. 2, n. 2, p. 01-38, mai.-ago./2019 


\section{Revista IBERC}

v. 2, n. 2, p. 01-38, mai.-ago./2019

www.responsabilidadecivil.org

os custos adicionais resultantes da infração ao direito da concorrência no preço praticado a jusante na cadeia de produção ou de distribuição. Compreende-se que assim seja. Na verdade, ao fazê-lo, o primitivo lesado está, no fundo, a afastar da sua esfera jurídica, total ou parcialmente, o dano. $O$ dado - e a solução para ele pensada - faz-nos dialogar com 0 problema da compensação de vantagens. Em regra, ela pode surgir quando, a partir da situação lesiva (ilícita e culposa), se gera não só um dano, como também um benefício, que compensa o primeiro. Uma das hipóteses tipicamente relevantes da problematização da compensatio lucri cum damno passa, exatamente, pela existência de um comportamento do lesado que, de algum modo, atenua os efeitos nefastos da agressão.

Tem-se entendido, a este propósito, que, nas hipóteses de conduta beneficiária do lesado, o lucro obtido só deve ser tido em conta se existisse da parte daquele o dever de minorar o dano. O problema tem sido, historicamente, ponderado à luz dos critérios do concurso de culpas do lesado. Paulo Mota Pinto refere que "estas vantagens (...) são de aferir segundo o ónus que sobre ele impende de não agravamento (...) dos danos, nos termos do artigo $570^{\circ} \mathrm{CC}^{\prime \prime 3}$. A este propósito estabelece-se, embora não unanimemente, a distinção entre as vantagens que resultam do cumprimento do dever de mitigar o dano (que devem ser compensadas com os danos) e aquelas que decorrem de um esforço que supera aquilo a que o lesado estava obrigado (que devem beneficiar a vítima. Note-se que enquanto os custos das primeiras devem ser suportadas pelo lesante, neste caso os custos ficam exclusivamente a cargo do lesado).

Explica o autor que "a compensação de vantagens resultantes da conduta do lesado está, pois, sujeita a um critério específico, prevalecente sobre a adequação ou a probabilidade da vantagem, que resulta dos ónus que impendem sobre o lesado de não contribuir para a produção ou agravamento dos danos"44. Mais adianta que "este critério aplica-se não só às vantagens resultantes de atividades apenas do lesado, como às resultantes de negócios celebrados pelo lesado com terceiros - designadamente, benefícios derivados de negócios de suprimento ou de cobertura do não cumprimento pelo inadimplente". Haverá que determinar se a celebração de tal contrato de cobertura era ou não possível e se era ou não exigível.

Repare-se que nem sempre se pode falar de compensação de vantagens, em sentido estrito, quando resulte da situação controvertida um benefício que atenua o dano sofrido. De facto, tem-se entendido que para se falar de c.l.c.d. tem de existir uma pluralidade de fenómenos. Ao invés, o jurista não haverá de fazer mais do que atender à conformação do

\footnotetext{
${ }^{43}$ PINTO, Paulo Mota. Interesse contratual negativo e interesse contratual positivoi. Coimbra: Coimbra Editora, 2009. p. 782.

${ }^{44}$ PINTO, Paulo Mota. Interesse contratual... p. 784.
}

Revista IBERC, Minas Gerais, v. 2, n. 2, p. 01-38, mai.-ago./2019 


\section{Revista IBERC}

v. 2, n. 2, p. 01-38, mai.-ago./2019

www.responsabilidadecivil.org

dano em concreto. Se a vantagem ainda se puder reconduzir à esfera de utilidades do bem objeto do direito subjetivo absoluto ou do interesse lesado, então a nossa conclusão é que não haverá independência das figuras e a compensação de vantagens mais não será do que um momento inerente à avaliação do dano. Se, pelo contrário, a utilização ou não daquele bem ou interesse, por si só, não se mostrar apta a explicar a emergência do benefício, então lidaremos com uma autónoma questão.

Em qualquer dos casos, não é um juízo de tipo lógico e causalista que nos oferece a solução do problema com que nos vemos confrontados. Ao invés, nos múltiplos exemplos que vão sendo avançados pela doutrina, percebemos que são valorações de outra índole que encaminham o jurista para a solução tida por justa. O apelo a uma ideia de exigibilidade - por mobilização da disciplina do artigo $570^{\circ} \mathrm{CC}$ - ou a ponderação do beneficiário da vantagem atribuída são espelho fiel disso, ao que se alia a preocupação eticamente conformada com os valores que, ora com a solução negativa, ora com a solução positiva, possam ser postos em causa.

O problema previsto no artigo $8^{\circ}, \mathrm{n}^{\circ} 1$, e a solução para ele pensada mantêm com a questão da compensação de vantagens uma proximidade inegável. Tal como nos típicos casos que podem ser compreendidos à luz da c.l.c.d., também aqui encontramos um comportamento do lesado que, a partir da situação de base, permite obter um ganho adicional que compensa os custos adicionais decorrentes da violação do direito da concorrência. A verdade, porém, é que, com base nesse comportamento, deixa de haver um dano (ou um dano tão grande como aquele que primitivamente poderia ser esperado) na esfera jurídica do primitivo lesado. Mais do que um problema de compensação de vantagens, estamos diante de uma verdadeira transferência do dano. Consoante ela seja total ou parcial, assim se excluirá ou reduzirá a indemnização. De outro modo não poderia deixar de ser: o problema coloca-se ao nível do próprio cômputo do dano.

Esta ideia resulta, aliás, da Diretiva, à luz da qual o regime legal deve ser interpretado. No considerando 39, pode ler-se que, quando um lesado tiver reduzido os seus danos emergentes (decorrentes da diferença entre o que foi efetivamente pago e o que teria sido pago na ausência da infração) através da sua repercussão nos seus adquirentes, a perda repercutida deixa de constituir um dano que deva ser indemnizado. Repare-se que, se com base na repercussão houver uma diminuição das vendas, gerando-se danos sob a forma de lucros cessantes, o dano não se apaga, razão pela qual o direito à indemnização não deve ser afetado. Embora a lei portuguesa nada disponha a esse respeito, é isso que resulta do funcionamento dos princípios (ou seja, do sistema ressarcitório à luz do qual o regime do private enforcement deve ser interpretado) e da Diretiva que se transpõe.

Revista IBERC, Minas Gerais, v. 2, n. 2, p. 01-38, mai.-ago./2019 


\section{Revista IBERC}

v. 2, n. 2, p. 01-38, mai.-ago./2019

www.responsabilidadecivil.org

A ideia de transferência do dano a que assim acedemos permite-nos compreender a solução consagrada no número 2 do preceito. Ao estabelecer-se que, nas ações de indemnização cujo pedido seja fundado na repercussão dos custos adicionais num cliente indireto, lhe cabe o ónus de provar a existência dessa repercussão e o seu âmbito, está-se, no fundo, a admitir que o lesado possa não ser o sujeito que, situando-se na cadeia de distribuição, contrata diretamente com aquele que violou as regras do direito da concorrência. Assume, por via da determinação normativa, a transferência do dano. O preceito revela-se importantíssimo por outro motivo. Com efeito, ao admitir-se que o cliente indireto possa ser titular do direito a uma indemnização, estamos no fundo a reconhecer - em abono do que já anteriormente explicitámos - que o pressuposto causal não pode continuar a ser entendido à luz da doutrina da causalidade adequada.

A essa luz, indagar-se-ia se é normal e adequado (provável) que da violação da norma de direito da concorrência resulte um dano do tipo do sofrido pelo cliente indireto, e a resposta afirmativa que para a indagação se pudesse encontrar basear-se-ia sempre numa pressuposição de que o comportamento humano é determinístico (ou seja, a reação do lesado direto seria sempre a mesma em face daquelas circunstâncias, o que implicaria a eliminação da componente de autodeterminação do sujeito). Nessa medida, percebe-se que o juízo a encetar não pode ser senão imputacional - não queremos saber se o dano (do cliente indireto) é causado pela violação da norma, mas sim se o dano que ele sofre pode ou não ser imputado àquela violação. Aqui, a resposta ficará dependente do âmbito de proteção dessa mesma norma: o comando normativo (que é preterido) visava ou não proteger aquele grupo de pessoas (no qual se integra o cliente indireto) contra aquele especial tipo de dano?

Posteriormente, haverá de se tentar determinar em que medida o comportamento do cliente direto (que interfere na situação controvertida) pode ser de molde a configurar uma perpetuação da infração cometida, podendo chamar para si parte da responsabilidade do primeiro agente, ou se simplesmente deve ser vista como uma resposta normal de um operador no mercado. Porque em causa está a ilicitude delitual na sua segunda modalidade, parece que a primeira alternativa deve ser negada, assumindo o primeiro lesante a responsabilidade globalmente considerada, de acordo com a lei. Mas resta-nos um segundo problema: é que o âmbito de proteção da norma que possa ser compreendida como disposição legal de proteção de interesses alheios não nos pode levar sem mais a tutelar, a este nível, interesses de um grupo não determinado de pessoas. De outro modo, correr-se-ia o risco de se fazer resvalar a responsabilidade para uma hiper-responsabilidade.

A disciplina consagrada relembra-nos, de facto, os problemas que envolvem os danos puramente patrimoniais, podendo resvalar-se, facilmente, para uma responsabilidade sem

Revista IBERC, Minas Gerais, v. 2, n. 2, p. 01-38, mai.-ago./2019 


\section{Revista IBERC}

v. 2, n. 2, p. 01-38, mai.-ago./2019

www.responsabilidadecivil.org

limites. Estes têm de ser introduzidos pela ponderação criteriosa do âmbito de proteção da norma, sobretudo tendo em conta que o legislador estabelece uma presunção de repercussão de custos adicionais.

Danos puramente patrimoniais são danos que ocorrem sem que sejam acompanhados da violação de direitos absolutos (ou, noutras latitudes, sem que haja lesão material da coisa ou da pessoa). A razão de ser para a não indemnizabilidade de princípio de tais danos passa exatamente pela possibilidade de, pela ausência de ilicitude, eles redundarem numa hiper-responsabilidade que contrariaria um ideal de justiça. Em face da possibilidade de se obter uma indemnização com base na violação de normas de direito da concorrência, deixamos de lidar com um vazio no que toca ao filtro objetivo de seleção das pretensões indemnizatórias procedentes: essa restrição, que impede os efeitos nefastos a que somos conduzidos quando nos confrontamos com a categoria dos danos puramente patrimoniais, é introduzida por via do âmbito de proteção da norma cuja preterição permite desvelar o caráter ilícito do ato.

Ora, tal norma não pode tutelar um grupo indeterminado de sujeitos ou um interesse em geral, sob pena de os mesmos inconvenientes que se pretendem obviar com a exigência da ilicitude se verificarem em concreto. Há, portanto, que ter em atenção as específicas normas de direito da concorrência que podem, uma vez violadas, desencadear o regime do private enforcement e perceber qual o âmbito de tutela que erigem. A dificuldade que resulta do artigo $8^{\circ}$ pode, portanto, passar por um alargamento desmedido do dever de indemnizar, que pode não corresponder a um ideal de justiça que a responsabilidade civil é chamada a desempenhar. Aliás, a diretiva mostra-se particularmente cuidadosa, nos seus considerandos, no que respeita à necessidade de conter o ressarcimento, evitando excessos. Fá-lo, contudo, por via de mecanismos atinentes ao cálculo da indemnização. Simplesmente, ao permitir-se, em obediência ao disposto na diretiva, que haja indemnização pela repercussão dos custos adicionais que seja feita, coloca-se o problema de saber qual o limite da responsabilidade.

O ponto merece a nossa atenção: na verdade, não se trata, aqui, de indemnizar os danos que tenham sido sofridos por vários sujeitos, mas de compensar os prejuízos que, não tendo sido sofridos pelo lesado, o são por terceiros a quem este, por via do mecanismo do mercado, os transmitiu. Não se verifica, no caso concreto, o alargamento dos credores de uma pretensão indemnizatória. A questão que importa resolver é, portanto, a de saber até que ponto os terceiros sobre quem é repercutido o custo adicional (e que assim suportam o dano) estão ou não integrados no âmbito de proteção da norma. Este parece-nos ser um dado do qual não se pode abdicar: onde falhar esta conexão de ilicitude claudica, também, a própria ilicitude em que se baseia a responsabilidade aqui desenhada.

Revista IBERC, Minas Gerais, v. 2, n. 2, p. 01-38, mai.-ago./2019 


Revista IBERC
v. 2, n. 2, p. 01-38, mai.-ago./2019
www.responsabilidadecivil.org

De acordo com o n. 3 do preceito, presume-se que houve repercussão de custos adicionais quando o réu cometer uma infração ao direito da concorrência; essa infração teve como consequência um custo adicional para o cliente direto do réu e o cliente indireto adquiriu os bens ou serviços afetados pela infração ou os bens ou serviços derivados dos bens ou serviços afetados pela infração ou que os contêm. Esta presunção ilidível vem dar resposta a dificuldades de prova que se poderiam verificar em concreto.

Com esta disciplina, o legislador parece dar acolhimento à ideia de liquidação do dano de terceiro ${ }^{45}$. Central para a compreensão da categoria, cuja admissibilidade levanta dúvidas à doutrina, é a noção de deslocação do dano, ou seja, o dano causado pela violação dos deveres que incumbem ao devedor atingiu um terceiro que não o credor, o que significa que todos os pressupostos da responsabilidade se verificam em relação a um sujeito, menos um, o dano, que se situa na esfera jurídica de outro, sendo imprescindível, segundo alguns autores, que esse dano seja previsível sem a intervenção do terceiro, o que implica que não há um alargamento do âmbito da responsabilidade, ao contrário do que sucede com a figura dos contratos com eficácia de proteção para terceiros.

Pensada para fazer face a algumas dificuldades no mundo contratual, parece ter sido transposta, ao nível do private enforcement do direito da concorrência, para o direito delitual.

\footnotetext{
${ }^{45}$ Sobre a figura, cf. NEUNER, Jörg. Der Schutz und die Haftung Dritter nach vertraglichen Grundsätzen. Juristenzeitung, 1999, p. 119 ss. e LARENZ, Karl. Zur Schutzwirkung eines Schuldvertrages gegenüber dritten Personen. Neue Juristische Wochenschrift, 1960, p. 78 ss.; VON SCHROETER, Hans-Ulrich. Die Haftung für Drittschäden. Jura, 1997, p. 343 s.; MATTAMOUROS, Jorge. A liquidação do dano de terceiro no direito civil português". RFDUP, III, 2006, p. 308 ss.; SÁ, Fernando. Contrato e liquidação de dano de terceiro - Análise de uma hipótese. Novas tendências da responsabilidade civil, Almedina, Coimbra, 2007. p. 207 ss.; FRADA, Carneiro da. Os deveres (ditos) acessórios e o arrendamento. Revista da Ordem dos Advogados, p. 268 ss.; DUARTE, Paulo. Reflexos jurídico-obrigacionais da cooperatividade nos negócios jurídicos celebrados pelas cooperativas de habitação e construção. Jurisprudência Cooperativa Comentada. Lisboa: INCM, 2012, p. 492 ss.; PINTO, Paulo Mota. Interesse contratual..., p. 804 s.; BARBOSA, Mafalda Miranda. Lições de Responsabilidade Civil, Princípia, 2017, n. 902. Para uma sistematização dos casos em que tipicamente se recorre à figura, PINTO, Paulo Mota. Interesse contratual..., p. 804 ss.; DUARTE, Paulo. Reflexos..., p. 492 s., referindo-se a três grupos de casos (casos em que o dano tem por objeto uma coisa que se encontra à guarda de outra pessoa que não é o seu dono, com base num contrato, v.g. de comodato, depósito; casos em que há uma relação de representação mediata ou fiduciária, de tal modo que o mandatário sem representação atua exclusivamente no interesse do terceiro; casos em que se verifica uma transferência do risco anterior à transferência da propriedade); FRADA, Carneiro da. Direito Civil. Responsabilidade civil. O método do caso. Coimbra: Almedina, 2006. p. 98 ss., falando de casos de mandato sem representação, contratos de depósito ou comodato, casos em que é efetuada a compra de determinada coisa a entregar em certo destino como local de cumprimento, sendo o comprador a agenciar o transporte, vindo a coisa a perecer durante a viagem por culpa do transportador, não podendo o vendedor que já não é proprietário pedir a indemnização e não sofrendo o comprador qualquer prejuízo, porque fica exonerado da contraprestação; SÁ, Fernando. Contrato e liquidação de dano de terceiro..., p. 207 ss, referindo-se aos casos de mandato sem representação, às situações que se colocam por força do funcionamento das regras sobre transferência do risco; às situações de propriedade fiduciária; aos casos geradores de uma obrigação de custódia ou de cuidado, aos casos de liquidação do dano por acordo (que, não obstante, acaba por deixar fora da liquidação do dano de terceiro em sentido próprio).
}

Revista IBERC, Minas Gerais, v. 2, n. 2, p. 01-38, mai.-ago./2019 


\section{Revista IBERC}

v. 2, n. 2, p. 01-38, mai.-ago./2019

www.responsabilidadecivil.org

No fundo, o primeiro lesado, ao repercutir os custos adicionais, funcionaria como um ponto de passagem para a ancoragem do dano num terceiro, esse sim o que seria efetivamente lesado. Com isto não se alarga a proteção delitual a todo e qualquer consumidor (ou a todo e qualquer fornecedor), o que equivaleria a proteger a este nível o mercado, mas ao cliente daquele que comete a infração. Admite-se é que, uma vez afastado o dano do cliente direto, possa beneficiar da tutela - podendo obter uma indemnização - o cliente indireto.

Diante da remissão para o artigo $483^{\circ} \mathrm{CC}$, a interpretação que se faça do regime da responsabilidade civil por violação das normas da concorrência não pode deixar de nos apontar no sentido de caminhos de restrição. Contra este entendimento não se invoque o teor literal do artigo $5^{\circ}$ Lei $n^{\circ} 23 / 2018$. Se o dano tiver sido causado por uma pequena ou média empresa (PME), esta apenas responde perante os seus próprios clientes ou fornecedores, diretos ou indiretos, se a sua quota em cada um dos mercados afetados pela infração ao direito da concorrência tiver sido inferior a $5 \%$ ao longo de toda a duração da infração, e se a aplicação das regras de responsabilidade solidária prejudicar de forma irremediável a sua viabilidade económica e desvalorizar totalmente os seus ativos. Responderá perante quaisquer outros lesados, se estes não puderem obter das outras empresas infratoras a reparação integral dos danos sofridos.

A restrição da responsabilidade das PME deixa de ter lugar se a empresa concretamente em causa tiver liderado uma infração ao direito da concorrência ou coagido outras empresas a participarem na infração, ou tiver sido anteriormente condenada, por decisão definitiva, por outra infração ao direito da concorrência. Já se o dano tiver sido causado por uma empresa beneficiária de dispensa de coima, esta apenas responde perante os seus próprios clientes ou fornecedores, diretos ou indiretos, respondendo perante quaisquer outros lesados apenas se estes não puderem obter das outras empresas infratoras a reparação integral dos danos sofridos. Quer isto dizer, a contrario, que o legislador parecia assumir que, em regra e fora situações excecionais determinadas por motivos espúrios à normal intencionalidade delitual, todos os danos decorrentes da infração sofridos por clientes ou fornecedores, diretos e indiretos, e por quaisquer outros lesados seriam indemnizáveis.

A ser aceite esta ideia em termos literais, tal redundaria numa hiper-responsabilidade, sem limites, a contrariar o sentido do justo. Significa, portanto, que competirá à doutrina (e à jurisprudência) a determinação dos critérios de seleção das pretensões indemnizatórias procedentes a este nível. Parecer ser essa, aliás, a intencionalidade da norma contida no artigo $3^{\circ}$, ao remeter expressamente para o artigo $483^{\circ} \mathrm{CC}$. Em rigor, e como veremos, o que o artigo $5^{\circ}$ faz é considerar que, no tocante à solidariedade, esta não será perfeita caso o infrator seja uma PME ou uma empresa beneficiária da dispensa de coima. Ou seja, nessas hipóteses

Revista IBERC, Minas Gerais, v. 2, n. 2, p. 01-38, mai.-ago./2019 


\section{Revista IBERC}

v. 2, n. 2, p. 01-38, mai.-ago./2019

www.responsabilidadecivil.org

especiais, a solidariedade só opera no limite da indemnização que seja devida aos clientes e fornecedores da própria empresa. Mas não quer significar que qualquer lesado possa vir a obter uma indemnização fora da consideração da teleologia/âmbito de proteção da norma.

Importa, a este propósito, ter em conta o disposto no artigo $19^{\circ}$ Lei $n^{\circ} 23 / 2018$, que prevê, no âmbito de uma ação popular, a possibilidade de uma indemnização em caso de indeterminação dos lesados. Parece aventar-se, portanto, a hipótese de um dano coletivo. Se não for possível identificarem-se os lesados e se a indemnização visa cobrir a integralidade dos danos, ficamos também sem critério de cálculo do quantum indemnizatório, havendo necessidade de recorrer ao critério previsto no artigo $9^{\circ} / 2$.

Sobre este ponto, há que tecer alguns esclarecimentos adicionais.

Os problemas relativos à indeterminação dos lesados não são novos, nem são desconhecidos, mesmo além-fronteiras. Eles colocam-se, sobretudo, em matéria de danos em massa. Pier Giuseppe Monateri ${ }^{46}$ considera que o grande problema dos mass torts passa pela própria estrutura do caso que abandona o esquema típico de referência em que A causa um dano a B sobre o seu património, dando origem a uma relação muito longa, muito dispersa, na qual é difícil reconduzir ao lesante as eventuais consequências que o autor invoca em juízo. Acresce que o dano é difuso, podendo tratar-se de um dano à própria sociedade no seu complexo, havendo muitos pequenos danos fragmentados por diversos sujeitos. Situando-se "fora da pré-compreensão normal ínsita ao modelo de responsabilidade", estes casos apresentam, segundo o ensinamento do autor, quatro características essenciais: difusão do dano, descompactação da contiguidade temporal entre a ação do lesante e o dano da vítima, problematicidade essencial do nexo causal, normal incapacidade do património do lesante para fazer frente à responsabilidade.

Simplesmente, essa indeterminação de que se cura não equivale à total ausência de identificação do lesado ou dos lesados, mas sim à constatação da dificuldade de se estabelecer o nexo causal exigível. A este propósito, Theo Bodewig ${ }^{47}$ refere que, nestes casos, a relação unidimensional entre lesados e lesantes (eindimensionele Beziehung zwischen Geschädigten und Tätern) é substituída por uma relação pluridimensional (mehrdimensiona), na sua dupla incerteza - para cada lesado surgem muitos alternativos lesantes (alternativ mehrere Täter); para cada agente surgem muitos alternativos lesados (alternativ mehrere Geschadigte). Ou seja, há que ter em conta que, em muitos casos, a alternative Täterschaft do

\footnotetext{
46 Veja-se, sobre o ponto, MONATERI, Pier Giuseppe. I mass tort: dalla RC al contratto politico. Responsabilità civile e previdenza, 1/2003, p. 13 e ss.

${ }^{47}$ BODEWIG, Theo. Probleme alternativer Kausalität bei Massenschäden..., p. 543.
}

Revista IBERC, Minas Gerais, v. 2, n. 2, p. 01-38, mai.-ago./2019 


\section{Revista IBERC}

v. 2, n. 2, p. 01-38, mai.-ago./2019

www.responsabilidadecivil.org

$\S 830 \mathrm{I} / 2$ BGB se torna mais complexa através de uma alternative Opferschaft (relativa às vítimas) $^{48}$.

A questão que é suscitada pelo artigo $19^{\circ}$ torna-se, pois, muito mais dilemática.

Conforme se pode ler no Acórdão de 29 de Novembro de 2016 do Supremo Tribunal de Justiça

"ao atribuir o direito de ação popular a todos, a lei permite que qualquer pessoa defenda interesses ou bens protegidos que não são apenas seus, mas de todos os nele interessados, pelo que o específico interesse processual do ato popular não é condicionado à existência de uma conexão substantiva entre o mesmo, individualmente considerado, e o bem tutelado, antes é originário, porque baseado na lei e radicado no direito fundamental dos cidadãos a participar na condução dos assuntos públicos".

Dito de outro modo, talvez mais incisivo, a existência de uma ação popular pressupõe um interesse que não seja um mero interesse individual. $O$ artigo $22^{\circ}$ da Lei $n^{\circ} 83 / 95$, de 31 de Agosto, alterada pelo DL $n^{\circ} 214-G / 2015$, de 2 de Outubro, prevê, no seu $n^{\circ} 2$, que a indemnização pela violação de interesses de titulares não individualmente identificados é fixada globalmente, tratando-se de interesses coletivos ou difusos ${ }^{49}$. Ora, podendo estar em causa interesses difusos ao nível do direito da concorrência, na aplicação da disciplina do private enforcement, o que releva ou o que devia relevar seria o interesse individual homogéneo, ou seja, a concretização do interesse coletivo ou difuso num sujeito individual. A indemnização global a que se alude tem de ter em conta os danos provocados no mercado globalmente considerado. Mas, um sujeito individual só poderá aceder à indemnização que lhe cabe se se integrar entre aqueles que a norma violada queria proteger. Lidamos, por isso, não com o potencial consumidor, mas como o consumidor-cliente.

\section{CONCLUSÕES}

\footnotetext{
${ }^{48}$ Para outras considerações sobre o ponto, cf. Mafalda Miranda BARBOSA, Do nexo de causalidade ao nexo de imputação, cap. X.

49 SOUSA, Miguel Teixeira de. Sobre a tutela jurisdicional do consumo e do ambiente. Centro de Direito do Consumo, Faculdade de Direito de Coimbra, 2000-2001, policopiado, p. 18 ss. Fala-nos de interesses difusos (os que correspondem a interesses supraindividuais, pelo que, pese embora possam refratar-se na esfera individual, transcendem-na necessariamente, sendo uma modalidade de interesses coletivos, e não se confundindo com a soma das posições individuais - cf. p. 2-3); interesses públicos (os interesses gerais da comunidade que abstraem dos interesses concretos que são satisfeitos - cf. p. 3). Dentro dos primeiros, o autor tem oportunidade de distinguir os interesses difusos stricto sensu, os interesses coletivos (os que pertencem a uma pluralidade indiferenciada de sujeitos entre os quais há uma relação que não é puramente de facto ou acidental, como por exemplo os interesses dos acionistas de uma sociedade comercial) e os interesses individuais homogéneos. Para Teixeira de Sousa (cf. Sobre a tutela ... p. 5), "o interesse coletivo resulta da concretização do interesse difuso lato sensu num grupo de interessados e o interesse individual homogéneo é a concretização de um interesse difuso stricto sensu ou de um interesse coletivo em sujeitos individuais".
}

Revista IBERC, Minas Gerais, v. 2, n. 2, p. 01-38, mai.-ago./2019 


Revista IBERC
v. 2, n. 2, p. 01-38, mai.-ago./2019
www.responsabilidadecivil.org

A lei $n^{\circ} 23 / 2018$, relativa ao regime do private enforcement da concorrência, ao mesmo tempo que estabelece regras especiais em matéria de responsabilidade civil por violação das regras de direito da concorrência, evidencia linhas de continuidade com a dogmática geral da responsabilidade delitual, ao ponto de 0 artigo $3^{\circ}$ remeter expressamente para o regime do artigo $483^{\circ} \mathrm{CC}$. Este dado é extremamente importante: ter consciência dele permite-nos mobilizar os principais vetores de responsabilização dos sujeitos, sem corrermos o risco de resvalar em situações de hiper-responsabilidade.

\section{BIBLIOGRAFIA}

AA. Vv. Digest Essential Cases on Natural Causation: 1 (Digest of European Tort Law), Springer-Verlag KG, 2007.

BARBOSA, Mafalda Miranda. Do nexo de causalidade ao nexo de imputação: contributo para a compreensão da natureza binária e personalística do requisito causal ao nível da responsabilidade civil extracontratual. Princípia, 2013.

BARBOSA, Mafalda Miranda. Lições de responsabilidade civil. Princípia, 2017.

BARBOSA, Mafalda Miranda. Private enforcement do direito da concorrência em Portugal: o antes, o agora e o depois da responsabilidade civil por violação de normas concorrenciais. $O$ Direito, 149, 2017/II.

BARBOSA, Mafalda Miranda. Responsabilidade Civil extracontratual: novas perspetivas acerca do nexo de causalidade. Princípia, 2014.

BÜGGERMEIER, Gert. Haftungsrecht. Struktur, Prinzipen, Schutzbereich zur Europäisierung des Privatrechts. Berlin: Springer, 2006.

BURBANK, Steven B.; FARHANG, Sean; KRITZER, Herbert M. Private enforcement. Lewis \& Clark Law Review, 17, 2013.

CANARIS, Claus-Wilhelm. Schutzgesetze-Verkehrspflichten-Schutzpflichten. Festschrift für Karl Larenz zum 80. Geburtstag am 23. April 1983, München: Beck, 1983.

CAPELO, Maria José; BARBOSA, Mafalda Miranda; HENRIQUES, Miguel Gorjão. Private Enforcement do direito da concorrência. Comentário à Lei n²3/2018, de 5 de Junho (no prelo).

CARAPINHA, Rui. O private enforcement do direito da concorrência à luz do direito português. Lisboa, 2014.

CORDEIRO, António Menezes. Da responsabilidade civil dos administradores das sociedades comerciais. Lex, 1997.

COSTA, Mario Júlio Almeida. Direito das Obrigações. 12. ed. Coimbra: Almedina, 2009.

Revista IBERC, Minas Gerais, v. 2, n. 2, p. 01-38, mai.-ago./2019 


\section{Revista IBERC}

v. 2, n. 2, p. 01-38, mai.-ago./2019

www.responsabilidadecivil.org

DEUTSCH. Allgemeines Haftungsrecht, 2. Aufl., Köln: Carl Heymanns, 1996.

DEUTSCH/AHRENS. Deliktrecht, Unerlaubte Handlungen, Schadensersatz und Schmerzensgeld. 4. Aufl., Köln: Carl Heymanns Verlag, 2002.

DÍEZ-PICAZO. Derecho de daños. Madrid: Civitas, 1999.

DÖRNER, Heinrich. Zur Dogmatik der Schutzgesetzverletzung. Juristische Schulung. Zeitschrift für Studium und Ausbildung, 27. Jahrgang, 1987.

ESSER/SCHMIDT. Schuldrecht - Allgemeiner Teil. Band I, Teilband 1, 8. Aufl., Heidelberg: C. F. Müller, 1995.

ESSER/SCHMIDT. Schuldrecht - Allgemeiner Teil. Band I, Teilband 2, 8. Aufl., Heidelberg: C. F. Müller, 2000.

FERRO, Miguel Sousa. Jurisprudência de private enforcement. Jurisprudência portuguesa de Direito da Concorrência, 2016. Disponível em: http://www.cideeff.pt/xms/files/Projeto_4_grupo_III/Jurisprudencia_de_Private_Enforcement.pdf . Acesso em 08 mai. 2019.

FIKENTSCHER/HEINEMANN. Schuldrecht. 10 Aufl., Berlin: De Gruyter, 2006.

GOTZLER, Max. Rechtsmässiges Alternativverhalten im haftungsbegründenden Zurechnungszusammenhang. München: Beck, 1977.

GRUNSKY, Wolfgang. Rezension: Max Gotzler, Rechtsmäßiges Alternativverhalten im haftungsbegründenden Zurechnungszusammenhang. Archiv für die civilistische Praxis, 178, Heft 2/3, 1978.

HANAU. Die Kausalität der Pflichtwidrigkeit: eine Studie zum Problem des pflichtmässigen Alternativverhaltens im bürgerlichen Recht. Göttingen: Schwartz, 1971.

HARKE, Jan Dirk. Allgemeines Schuldrecht. Heidelberg: Springer, 2010.

KNÖPFLE, Robert. Zur Problematik der Beurteilung einer Norm als Schutzgesetz um Sinne des $\S 823$ Abs. 2 BGB, Neue Juristische Wochenschrift, 1967.

KOHTE, Wolfhard. Normzweck und Interessenabwägung bei der Auslegung des § 823 II BGB, - BGH NJW 1987, 1818. Jura, 1988, Heft 3.

KOZIOL, H. Rechtsmäßiges Alternativverhalten- Auflockerung starrer Lösungsansätze. Festschrift für E. Deutsch zum 70. Geburtstag. H. J. Ahrens; Christian von Bar; A. Spickhoff; J. Taupitz (Hrsg.), Köln: Heymann, 1999.

KERSTING, Christian. Transposition of the antitrust damage directive into German Law. The EU Antitrust Damages Directive: Transposition in the Member States, Oxford University Press, 2017. Disponível em: https://papers.ssrn.com/sol3/papers.cfm?abstract_id=2998586. Acesso em 08 mai. 2019.

LANGE, Hermann; SCHIEMANN, Gottfried. Handbuch des Schuldrechts - Schadensersatz. 3. Aufl., Tübingen: Mohr, 2003.

Revista IBERC, Minas Gerais, v. 2, n. 2, p. 01-38, mai.-ago./2019 


\section{Revista IBERC}

v. 2, n. 2, p. 01-38, mai.-ago./2019

www.responsabilidadecivil.org

LARENZ, Karl. Lehrbuch des Schuldrechts - Allgemeiner Teil. Band 1, 14 Aufl., München: Verlag C. H. Beck, 1988.

LARENZ, Karl. "Präventionsprinzip und Ausgleichsprinzip im Schadensersatzrecht". Neue Juristische Wochenschrift, 59.

LARENZ/CANARIS. Lehrbuch des Schuldrechts. Band II, Halbband 2, 13 Aufl., München: Verlag C. H. Beck, 1994.

LEITÃo, AdelAide Menezes. Normas de protecção e danos puramente patrimoniais, Almedina, Coimbra, 2009.

LINDENMAIER. Adäquate Ursache und nächste Ursache. Zur Kausalität im allgemeinen bürgerlichen Recht und in den Allgemeinen Deutschen Seeverischerungsbedingungen. Festschrift für Wüstendörfer, Zeitschrift für das Gesamte Handelsrecht und Konkursrecht, Band 113, 3/4, 1950.

MEDICUS, Dieter. Bürgerliches Recht. 21 Aufl., Köln: Carl Heymanns Verlag, 2007.

MONATERI, Pier Giuseppe. I mass tort: dalla rc al contratto politico. Responsabilità civile e previdenza, $1 / 2003$.

MONTEIRO, Jorge Sinde. Responsabilidade por conselhos, informações e recomendações. Coimbra: Almedina, 1989

MONTEIRO, Jorge Sinde. Définition de la causalité: la causalité dans les projets nationaux. Disponível em : http://grerca.univ-rennes1.fr/digitalAssets/267/267958_jsmonteiro.pdf. Acesso em 08 mai. 2019.

MONTIJANO, Martín García-Ripoll. Imputación objetiva, causa próxima y alcance de los daños indemnizables. Granada: Editorial Comares, 2008.

OLIVEIRA, Nuno Manuel Pinto de. O problema da ilicitude das condutas conformes às leis de protecção do ambiente. Acórdão do Supremo Tribunal de Justiça de 17.1.2002. Cadernos de Direito Privado, n. 12, Outubro/Dezembro, 2005.

RISTOW, Till. Die psychische Kausalität im Deliktsrecht. Europäische Hochschulschriften, Frankfurt am Main: Peter Lang, 2003.

RÜMELIN. Die Verwendung der Causalbegriffe im Straf und Civilrecht. Archiv für die civilistiche Praxis, 90, Heft 2, 1900.

SCHICKEDANZ, Erich. Schutzwecklehre und Adäquanztheorie. Neue Juristische Wochenschrift, 24. Jahrgand, 1. Halbband, 1971.

SERRA, Adriano Vaz. Requisitos da responsabilidade civil. Boletim do Ministério da Justiça, n. 92.

SERRA, Adriano Vaz. Obrigação de indemnização. Colocação. Fontes. Conceito e espécies de dano. Nexo causal. Extensão do dever de indemnizar. Espécies de indemnização. Direito de abstenção e de remoção. Boletim do Ministério da Justiça, n. 84, março 1959. 


Revista IBERC
v. 2, n. 2, p. 01-38, mai.-ago./2019
www.responsabilidadecivil.org

SOUSA, Miguel Teixeira de. Sobre a tutela jurisdicional do consumo e do ambiente. Centro de Direito do Consumo, Faculdade de Direito de Coimbra, 2000-2001.

SOUSA, Rabindranath Capelo de. Teoria Geral do Direito Civil. Coimbra: Coimbra Editora, 2003.

STOLL, Hans. Kausalzusammenhang und Normzwek im Deliktsrecht. Tübingen: Mohr, 1968.

STOLL, Hans. Haftungsverlagerung durch beweisrechtliche Mittel. Archiv für die civilistische Praxis, 176, 1976.

TRAEGER. Der Kausalbegriff im Straf und Zivilrecht. Malburg: Elwert, 1904.

VAN DEN BERGH, Roger. Competition law and the persistng collective action problema. Maastricht Journal of European and Comparative Law, 20, 2013.

VARELA, Antunes. Das obrigações em geral. v. 1, Coimbra: Almedina, 2003.

VASCONCELOS, Maria João Pestana de. Algumas questões sobre a ressarcibilidade delitual de danos puramente patrimoniais no ordenamento jurídico português. Novas tendências da responsabilidade civil, Almedina, 2009.

VIEWEG, Klaus. Schadensersatezrecht. J. Von Staudinger Kommentar zum BGB, 13. Aufl., Berlin: De Gruyter, 2005.

VON BAR, Christian. Delilktsrecht - Empflieht es sich, die Voraussetzungen der Haftung für unerlaubte Handlungen mit Rücksicht auf die gewandelte Rechtswirklichkeit und die Entwicklungen in Rechtsprechung und Lehre neu zu ordnen? Wäre es insbesondere zweckmässig, die Grundtatbestände der § 823 Abstätze 1 und 2, § 826 BGB zu erweitern oder zu ergänzen? Gutachten und Vorschläge zur überarbeitung des Schuldrechts herausgegeben vom Bundesminister der Justiz, Bd. II, Köln: Bundesanzeiger Verlagsges, 1981, p. 1696 ss.

VON CAEMMERER, Ernst. Die Bedeutung des Schutzbereichs einer Rechtsnorm für die Geltendmachung von Schadensersatzansprüchen aus Verkehrsunfällen. Deutsches Autorecht 70.

VON CAEMMERER, Ernst. Das Problem der überholenden Kausalität im Schadensersatzrecht. Gesammelte Schriften, Bd. 1, 1962.

WESTERMANN; BYDLINSKI; WEBER. BGB - Schuldrecht Allgemeiner Teil. 6. Aufl., Heidelberg: C.F. Müller, 2007.

WISSMANN. Die Berufung auf rechtsmässiges Alternativverhalnten“. Neue Juristische Wochenschrift, 71.

WOODS, Donncadh; SINCLAIR, Alisa; ASHTON, David. Private enforcement of community competition law: modernisation and the road ahead. Competition Policy Newsletter, 2, 2004. 


\section{Revista IBERC}

v. 2, n. 2, p. 01-38, mai.-ago./2019

www.responsabilidadecivil.org

Como citar: BARBOSA, Mafalda Miranda. Da responsabilidade civil por violação de normas da concorrência ao novo regime do private enforcement da concorrência: disrupção ou continuidade em relação ao modelo delitual português? Revista IBERC, Minas Gerais, v. 2, n. 2, p. 1-33, mar.-jun./2019. 